\title{
Federalism and Mitigating Climate Change: The Merits of Flexibility, Experimentalism, and Dissonance
}

Reich, Johannes

\begin{abstract}
Federalism is ostensibly misplaced to mitigate climate change as a global public concern as it is prone to import the inadequate incentive structures existing at the international level into the domestic domain. Drawing from the legal structures and procedures of Swiss federalism, this article attempts to provide a more nuanced assessment of the relationship between laws designed to mitigate climate change and federalism. It seeks to demonstrate that federalism may support effective policies to mitigate climate change, provided that the architecture of domestic climate change law meets certain criteria. These include considerable federal powers, a degree of institutional flexibility, robust formal channels of influence for subnational actors on policy formulation at the federal level, ample room for regulatory experimentalism at the lower layers of federalism, and the 'right to act' conferred on the Federation to avoid political impasse among the constituent units.
\end{abstract}

DOI: https://doi.org/10.1017/s2047102521000121

Posted at the Zurich Open Repository and Archive, University of Zurich

ZORA URL: https://doi.org/10.5167/uzh-203363

Journal Article

Published Version

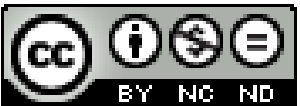

The following work is licensed under a Creative Commons: Attribution-NonCommercial-NoDerivatives 4.0 International (CC BY-NC-ND 4.0) License.

Originally published at:

Reich, Johannes (2021). Federalism and Mitigating Climate Change: The Merits of Flexibility, Experimentalism, and Dissonance. Transnational Environmental Law, 10(2):263-291.

DOI: https://doi.org/10.1017/s2047102521000121 


\title{
Federalism and Mitigating Climate Change: The Merits of Flexibility, Experimentalism, and Dissonance ${ }^{\dagger}$
}

\author{
Johannes Reich*
}

\begin{abstract}
Federalism is ostensibly misplaced to mitigate climate change as a global public concern as it is prone to import the inadequate incentive structures existing at the international level into the domestic domain. Drawing from the legal structures and procedures of Swiss federalism, this article attempts to provide a more nuanced assessment of the relationship between laws designed to mitigate climate change and federalism. It seeks to demonstrate that federalism may support effective policies to mitigate climate change, provided that the architecture of domestic climate change law meets certain criteria. These include considerable federal powers, a degree of institutional flexibility, robust formal channels of influence for subnational actors on policy formulation at the federal level, ample room for regulatory experimentalism at the lower layers of federalism, and the 'right to act' conferred on the Federation to avoid political impasse among the constituent units.
\end{abstract}

Keywords: Federalism, Climate change mitigation, Environmental federalism, Energy federalism, Switzerland, Climate change law

\section{FEDERALISM AND CLIMATE CHANGE MITIGATION LAW: AN ANTAGONISTIC RELATIONSHIP?}

'Nature', no less, 'made your country federal', conceded Napoléon Bonaparte in a letter to Swiss deputies on 10 December $1802 .^{1}$ The irony of this observation by the First

$\dagger$ This contribution is part of a collection of articles growing out of the workshop 'The Law of Energy Transition in Federal Systems', held by the University of Tübingen, Faculty of Law, and the University of North Carolina at Chapel Hill, School of Law, in Tübingen (Germany), 27 June 2019.

* University of Zurich (Switzerland).

Email: johannes.reich@rwi.uzh.ch.

I would like to thank two anonymous referees for their insightful comments.

1 Letter from Consul Bonaparte to the Swiss Deputies (Saint-Cloud (France), 10 Dec. 1802), reprinted in J. Strickler \& A. Rufer (eds), Actensammlung aus der Zeit der Helvetischen Republik IX (1798-1803) 
Consul of the First French Republic - who soon thereafter crowned himself 'Emperor of the French' and reshaped the political landscape of the European Continent - was hardly lost on his contemporaries. After all, it was invading French troops that ignited and supported the 'Helvetic Revolution'. ' This uprising of 1798 swept away the Ancien Régime - the 'Old Swiss Confederacy' of 'quasi-sovereign petty states', associates, and joint dependencies ${ }^{3}$ - and put in its place a unitary state under French hegemony: the Helvetic Republic. ${ }^{4}$ Centralism proved to be a short-lived interlude on Swiss territory, however. The Act of Mediation of 19 February 1803, imposed by Napoléon in the wake of his letter, paved the way for Switzerland to be transformed into a federal state of constituent units with equal powers in $1848 .{ }^{5}$ Switzerland has since evolved into one of only 'three classic federations ${ }^{\prime 6}$ worldwide, a 'paradigmatic case" ${ }^{\text {" }}$ of federalism and 'a role model of a federal polity in Europe'. 8 The country's 2,199 territorial and political authorities - the federal government (Federation), the 26 constituent units (cantons ${ }^{9}$ ), and the 2,172 municipalities ${ }^{10}$ - assembled on an area of less than 42,000 square kilometres inhabited by 8.7 million people ${ }^{11}$ bear witness to Switzerland's 'extreme decentralization'. 12

These intertwining legal structures provide a unique setting to gain a deeper understanding of the relationship between federalism and laws that mitigate climate change. For reasons of climate physics, this relationship is ostensibly antagonistic. Carbon dioxide $\left(\mathrm{CO}_{2}\right)$, methane, nitrous oxide and fluorinated gases are defined as greenhouse gases (GHGs) because of their capacity to partially absorb thermal radiation from

(Stämpfli, 1903), pp. 876-8, at 876 ('La nature a fait votre Etat fédératif'), available at: https://www.amtsdruckschriften.bar.admin.ch/start.do.

2 See A. Holenstein, 'Beschleunigung und Stillstand: Spätes Ancien Régime und Helvetik (1712-1802/03)', in G. Kreis (ed.), Die Geschichte der Schweiz (Schwabe, 2014), pp. 310-61, at 353-4.

3 Th. Maissen, 'The Swiss Confederacy: A Constitutional Model and Anti-Model for the Founding Fathers', in S. Krause (ed.), Theories of Modern Federalism (Nomos, 2019), pp. 49-69, at 49-50.

4 See A. Fankhauser, 'République helvétique' (27 Jan. 2011), in Dictionnaire historique de la Suisse, available at: https:/hls-dhs-dss.ch/fr/articles/009797/2011-01-27; Th. Maissen, Geschichte der Schweiz, $6^{\text {th }}$ edn (Hier \& Jetzt, 2019), pp. 160-2.

5 See Maissen, n. 4 above, pp. 170-2.

6 D.J. Elazar, Federal Systems of the World: A Handbook of Federal, Confederal and Autonomy Arrangements, $2^{\text {nd }}$ edn (Longman, 1994), p. 246.

7 Th.O. Hueglin \& A. Fenna, Comparative Federalism: A Systematic Inquiry, $2^{\text {nd }}$ edn (University of Toronto Press, 2015), p. 121.

8 M. Burgess, Comparative Federalism: Theory and Practice (Routledge, 2006), p. 117 (according to whom Switzerland is 'widely considered to be the role model of a federal polity in Europe').

9 'Canton' (plural 'cantons') is derived from the Latin 'canton' (angle, landscape, place) and has prevailed as the main designation for Switzerland's constituent units since the Helvetic Revolution: A. Kley, 'Cantons' (13 Apr. 2006), in Dictionnaire historique de la Suisse, available at: https://hls-dhs-dss.ch/fr/ articles/026414/2016-04-13.

10 Federal Statistical Office, 'Les 2172 communes de la Suisse au 1.1.2021' (2021), available at: https://www.atlas.bfs.admin.ch/maps/13/fr/15739_229_228_227/24617.html.

11 Federal Statistical Office, 'Population résidante permanente selon la catégorie de nationalité, l'âge et le canton, 3e trimestre 2020' (2020), available at: https:/www.bfs.admin.ch/bfs/fr/home/statistiques/population/effectif-evolution/population.assetdetail.14941423.html.

12 L. Thorlakson, 'Comparing Federal Institutions: Power and Representation in Six Federations' (2003) 26(2) West European Politics, pp. 1-22, at 18. 
the earth's surface. ${ }^{13} \mathrm{CO}_{2}$ accounts for around three quarters of all GHG emissions. ${ }^{14}$ Multiple lines of evidence indicate a causal and 'almost linear relationship between cumulative $\mathrm{CO}_{2}$ emissions and projected global temperature change'. ${ }^{15}$ Climate change induced by increased concentration of $\mathrm{CO}_{2}$ 'remains largely irreversible for 1,000 years after emissions stop'. ${ }^{16}$ Each tonne of $\mathrm{CO}_{2}$ emitted into the atmosphere anywhere on earth at any given time had, has and will have an almost identical effect on the average global temperature. Climate change therefore constitutes a global public good. ${ }^{17}$ For an individual country there is thus little incentive to reduce its GHG emissions unilaterally. Federalism appears to duplicate these inadequate incentive structures at the domestic level, further hampering policy measures to mitigate climate change effectively.

Drawing from the legal structures and procedures of Swiss federalism, this article attempts to provide a more nuanced assessment of the relationship between federalism and the laws and regulations designed to mitigate climate change. It seeks to demonstrate that federalism may support effective policies to mitigate climate change provided that the relevant framework of constitutional, administrative, and environmental law meets certain criteria. These include a degree of institutional flexibility, constitutional provisions to avoid stalemate among the entities of the federation, robust federal powers, and autonomy at the subnational level allowing for regulatory experimentalism and innovation. The article reaches its conclusion in five steps. It briefly clarifies the relevant taxonomy and carves out the constitutional foundations of Swiss federalism (Section 2) in order to trace the formative influence of federalism on the architecture of Switzerland's domestic climate change law (Section 3). The heuristics gained based on economic approaches to federalism (Section 4) help to analyze the procedures of domestic climate change law. These rest on relatively broad federal powers and are

13 See Annex A to the Kyoto Protocol to the United Nations Framework Convention on Climate Change (UNFCCC, n. 65 below), Kyoto (Japan), 10 Dec. 1997, in force 16 Feb. 2005, available at: https://unfccc.int/resource/docs/convkp/kpeng.pdf (ratified by Switzerland on 9 July 2003, No. 0.814.011, available at: https://www.admin.ch/opc/fr/classified-compilation/20021138/index.html; authentic French version), including the 'Doha Amendment', Doha (Qatar), 8 Dec. 2012, in force 31 Dec. 2020, available at: https://unfccc.int/files/kyoto_protocol/application/pdf/kp_doha_amendment_english.pdf (ratified by Switzerland on 28 Aug. 2015, available at: https://www.fedlex.admin.ch/eli/oc/2020/926/fr). Correspondingly, Ordinance on the Reduction of $\mathrm{CO}_{2}$ Emissions (Federal $\mathrm{CO}_{2}$ Ordinance), 30 Nov. 2012, No. 641.711, Art. 1(1); official titles: Verordnung über die Reduktion der $\mathrm{CO}_{2}$-Emissionen (German), Ordonnance sur la réduction des émissions de $\mathrm{CO}_{2}$ (French), Ordinanza sulla riduzione delle emissioni di $\mathrm{CO}_{2}$ (Italian), available at: https://www.admin.ch/opc/en/classified-compilation/20120090/index.html (non-official English translation).

14 'Summary for Policymakers', in Intergovernmental Panel on Climate Change (IPCC) (Core Writing Team, R.K. Pachauri \& L.A. Meyer (eds)), Climate Change 2014: Synthesis Report: Contribution of Working Groups I, II and III to the Fifth Assessment Report of the IPCCC (IPCC, 2015), pp. 2-31, at 5 (regarding 1970-2010), available at: https://www.ipcc.ch/site/assets/uploads/2018/05/SYR_AR5_ FINAL_full_wcover.pdf.

15 Ibid., p. 8.

16 S. Solomon et al., 'Irreversible Climate Change due to Carbon Dioxide Emissions' (2009) 106(6) Proceedings of the National Academy of Sciences of the United States of America, pp. 1704-9, at 1704, available at: https://www.pnas.org/content/pnas/106/6/1704.full.pdf.

17 See also W.D. Nordhaus, 'Climate Change: The Ultimate Challenge for Economics' (2019) 109(6) American Economic Review, pp. 1991-2014, at 1993; R.N. Stavins, 'The Problem of the Commons: Still Unsettled after 100 Years’ (2011) 101(1) American Economic Review, pp. 81-108, at 83, 98. 
embedded in an intertwined network of horizontal cooperation (Section 5), which allows for regulatory experimentalism at the levels of both the cantons and urban municipalities (Section 6). Methodologically, the article is founded on an analytical examination of the incentives which the framework of constitutional, administrative, and environmental law provides to the Federation, the cantons, and the municipalities. ${ }^{18}$

\section{CONSTITUTIONAL FOUNDATIONS OF SWISS FEDERALISM}

\subsection{Comparing Federalism: Taxonomy}

'Federalism' has taken on different meanings on both sides of the Atlantic since the $18^{\text {th }}$ century. ${ }^{19}$ While the Swiss Federalists opposed a robust, centralized political authority during the Helvetic Republic, American Federalists favoured strong central governance. ${ }^{20}$ This ambiguity traces back to the Latin word foedus (league) from which the terms 'federal', 'federation', and 'federalism' are derived. ${ }^{21}$ These etymological roots allow groups to refer to the same concept (federalism) while emphasizing different aspects of its semantic content in order to pursue opposing political ends - favouring unity over centrifugal tendencies (American Federalists) or stressing the constituent unit's autonomy (Swiss Federalists). Such conceptual ambiguities call for scholarship in comparative law to rest on precise taxonomy. 'Federation', 'federalism', and 'federal' all refer to structures of political governance combining shared rule with self-rule. ${ }^{22}$ Political entities ranging from federal states to confederacies and supranational organizations thus all form 'federal polities' (or 'federal systems'). ${ }^{23}$ As a more specific subcategory, a 'federation' (or 'federal state') is a territorial and political entity based on a constitution that allocates political power between a general entity (federal or central government: 'the Federation') and a number of regional entities (constituent units such as provinces, cantons or states), with each of these entities fulfilling tasks relating to matters on which they are entitled to take binding and final decisions ('noncentralization'). ${ }^{24}$ The constituent units and the federal government thus 'exercise concurrent authority over the people'. ${ }^{25}$ As a result of the dual composition of

18 For broadly similar approaches in legal regulatory theory see, e.g., R. Baldwin, M. Cave \& M. Lodge, Understanding Regulation: Theory, Strategy, and Practice, $2^{\text {nd }}$ edn (Oxford University Press, 2012), pp. 25-69 (on theories of regulation and on 'good regulation'), or A.I. Ogus, Regulation: Legal Form and Economic Theory (Hart, 2004), pp. 3-6, 29-54 (on theories and public interests for regulation).

19 Maissen, n. 3 above, p. 49.

20 A. Fankhauser, 'Fédéralistes' (28 Jan. 2005), in Dictionnaire historique de la Suisse, available at: https:/hls-dhs-dss.ch/fr/articles/017368/2005-01-28; Maissen, n. 4 above, pp. 165-6; A.R. Amar, America's Constitution: A Biography (Random House, 2006), pp. 35-7, 43-53.

21 Maissen, n. 3 above, p. 49.

22 D.J. Elazar, Exploring Federalism (University of Alabama Press, 1987), pp. 34-8.

23 See R.L. Watts, 'Federalism, Federal Political Systems, and Federations' (1998) 1(1) Annual Review of Political Science, pp. 117-37, at 121; W.H. Riker, Federalism, $4^{\text {th }}$ edn (Little Brown, 1964), p. 101; R.P. Inman \& D.L. Rubinfeld, Democratic Federalism (Princeton University Press, 2020), pp. 8, 21, 301-5; Burgess, n. 8 above, pp. 226-47 (on the European Union).

24 See, e.g., Elazar, n. 22 above, p. 34; Inman \& Rubinfeld, n. 23 above, pp. 8-11; Riker, n. 23 above, p. 11; Watts, n. 23 above, p. 121.

25 Printz v. United States, 521 U.S. 898, 920 (1997). 
federations, ${ }^{26}$ it is both the Swiss People and the 26 individual cantons that constitute Switzerland, according to the first provision of the Swiss Federal Constitution. ${ }^{27}$ Finally, 'federalism' refers to both the normative theory and the institutional practice of legitimizing and advocating a political and legal order committed to non-centralization. ${ }^{28}$

In some federal states (such as Brazil, Canada, and the United States (US)), both the federation and the constituent units have their own civil service and judiciary to implement and adjudicate on their own laws. Such arrangements are referred to as 'horizontal' or 'dualist' federalism. Political structures such as Germany or Switzerland, in principle relying on the constituent units to implement federal and subnational laws alike, are labelled 'integrated', 'executive', or 'administrative' federalism. ${ }^{29}$ In this article, such systems are defined as 'administrative interlocking, ${ }^{30}$ The term highlights both the vertical (Federation/constituent units) and horizontal (among constituent units) intertwinement ${ }^{31}$ within the federal polity. The term 'horizontal cooperative federalism' refers to institutionalized cooperation among constituent units. ${ }^{32}$

\subsection{Swiss Federalism: A Constitutional Compromise and an Enduring Legacy}

The constitutional framework of Swiss federalism, forming the background of the country's domestic climate change law, can be traced back to the first Federal Constitution. Prior to the enactment of the Federal Constitution on 12 September 1848, escalating tensions between liberal-Protestant and conservative-Catholic cantons had erupted into the brief civil war of 1847-48 (the Sonderbund War), in which an alliance of conservative cantons - the Sonderbund ${ }^{33}$ - suffered a resounding defeat. ${ }^{34}$ This outcome paved the way to converting the Swiss Confederacy into a federal state. ${ }^{35}$ Federalism was

26 See J. Madison, 'The Conformity of the Plan to Republican Principles', Federalist Papers, No. 39, 16 Jan. 1788 (stating that both the constituent states and 'the individual citizens' compose the nation), available at: https://avalon.law.yale.edu/18th_century/fed39.asp.

27 Swiss Federal Constitution, 18 Apr. 1999, No. 101, Art. 1; official titles: Bundesverfassung der Schweizerischen Eidgenossenschaft (German), Constitution fédérale de la Confédération suisse (French), Costituzione federale della Confederazione Svizzera (Italian), available at: https://www.admin.ch/opc/en/classified-compilation/19995395/index.html (non-official English translation).

28 But see, e.g., W.S. Livingston, 'A Note on the Nature of Federalism' (1952) 67(1) Political Science Quarterly, pp. 81-95, at 85 (federalism being a function of societies).

29 See Hueglin \& Fenna, n. 7 above, pp. 54-5; J. Poirier \& Ch. Saunders, 'Comparing Intergovernmental Relations in Federal Systems: An Introduction', in J. Poirier, Ch. Saunders \& J. Kincaid (eds), Intergovernmental Relations in Federal Systems (Oxford University Press, 2015), pp. 1-13, at 6.

30 See Burgess, n. 8 above, p. 119 ('[a]dministrative (interlocking) federal practice').

31 See F.W. Scharpf, B. Reissert \& F. Schnabel, Politikverflechtung: Theorie und Empirie des kooperativen Föderalismus in der Bundesrepublik (Scriptor Verlag, 1976), p. 21 (the seminal work defining the German term 'Politikverflechtung', which loosely translates as 'political and administrative intertwinement').

32 See, e.g., A. Vatter, Swiss Federalism: The Transformation of a Federal Model (Routledge, 2018), p. 65; see Section 5.2 below.

33 See R. Roca, 'Sonderbund' (20 Dec. 2012), in Dictionnaire historique de la Suisse, available at: https://hls-dhs-dss.ch/fr/articles/017241/2012-12-20.

34 Th. Maissen, 'Fighting for Faith? Experiences of the Sonderbund Campaign 1847', in J. Charnley \& M. Pender (eds), Switzerland and War (Lang, 1999), pp. 9-42, at 14.

35 Switzerland is thus a 'federation' (federal state) in all but its official name in three of the four national languages as well as in English ('Swiss Confederation'); see Swiss Federal Constitution, n. 27 above, 
tantamount to a pragmatic compromise to peacefully accommodate the defeated cantons of the former Sonderbund in the federal state. ${ }^{36}$ The following constitutional principles, unaltered since 1848, shape Switzerland's characteristic small-scale federalism with regard to climate change mitigation and beyond.

\section{Symmetrical federalism}

All 26 cantons have equal and original powers (symmetrical horizontal allocation of powers). ${ }^{37}$ As a result of this symmetrical federalism, the Federal Parliament (the Federal Assembly) consists of two chambers - the National Council and the Council of States - each having identical powers. Each canton elects two members of the Council of States, regardless of its size, except for six cantons that emerged from partitions. ${ }^{38}$ The Federal Assembly elects the seven members of the executive branch of the federal government (the Federal Council). ${ }^{39}$

\section{Residual powers of the cantons}

All powers not ascribed to the Federation by the Federal Constitution are retained by the cantons. ${ }^{40}$ Expanding federal powers thus requires an amendment to the Federal Constitution. All amendments to the Federal Constitution are subject to a referendum. ${ }^{41}$ Such referenda demand a cumulative majority of both the voters and the cantons in order to be approved. ${ }^{42}$

\section{Administrative interlocking ${ }^{43}$}

The cantons not only implement their own laws but also those of the Federation subject to an explicit provision in the Federal Constitution or in federal statutory law. ${ }^{44}$ Even in areas where the Federation has the 'right to decide' (power to legislate, policy formulation), the cantons therefore usually retain the 'right to act'

Arts 1 and 2(2) (in its national languages that are Romanic languages: Confédération suisse (French), Confederazione Svizzera (Italian), Confederaziun svizra (Romansh)).

36 See Maissen, n. 4 above, pp. 200-2; Vatter, n. 32 above, pp. 169, 229.

37 See Swiss Federal Constitution, n. 27 above, Arts 1 and 3.

38 Ibid., Arts 148(2) and 150(2).

39 Ibid., Art. 175(2).

40 Ibid., Art. 3, $1^{\text {st }}$ sentence (the cantons exercising all powers not vested in the Federation).

41 J. Reich, 'Switzerland: The State of Liberal Democracy', in R. Albert et al. (eds), 2017 Global Review of Constitutional Law (I•CONnect \& Clough Center for the Study of Constitutional Democracy at Boston College, 2018), pp. 280-5, at 280-3 (on Swiss direct democracy and its consequences), available at: https://doi.org/10.5167/uzh-158512.

42 Swiss Federal Constitution, n. 27 above, Arts 3, 42(1) and 140(1a).

43 On the taxonomy see Section 2.1 above.

44 See Swiss Federal Constitution, n. 27 above, Art. 46(1) (stipulating that the 'Cantons shall implement federal law in accordance with the Federal Constitution and federal legislation' with the effect that the Federation may, on the basis of either the Federal Constitution or federal statutory law, provide for an implementation by its own [federal] administration. See, e.g., Swiss Federal Court, Decision 127 II 49, 26 Jan. 2001, s. 3, available at: https://www.bger.ch. The Swiss Federal Court is 'the supreme judicial authority' of the Swiss Federation (Swiss Federal Constitution, n. 27 above, Art. 188(1)) and thus Switzerland's highest supreme court; see Reich, n. 41 above, p. 281. 
(policy implementation). ${ }^{45}$ This enables the cantons to partly adjust federal laws to their own preferences, especially when the policy objectives are unclear or political consensus is weak. ${ }^{46}$ Federal authorities lack any power to appoint or dismiss the civil servants of the cantons implementing federal law.

\section{Participation of the cantons in the decision-making process of the Federation}

The cantons take part in the decision-making processes at the federal level. ${ }^{47}$ Each canton has the right to be consulted on both important federal legislation and international treaties before the drafts are prepared and submitted to the Federal Parliament. ${ }^{48}$ This consultation procedure is owed largely to the right of eight cantons or 50,000 citizens to launch a referendum against any federal statutory law and most international treaties approved by the Federal Parliament. ${ }^{49}$ Empirically, such optional referenda are launched against around a mere $6 \%$ of all legislative acts that are constitutionally subject to this institution of direct democracy. ${ }^{50}$ Roughly half of all federal acts actually put to an optional referendum have been vetoed at the ballot box since $1874 .{ }^{51}$ The considerable political uncertainty fostered by the optional referendum creates strong incentives to seek broad parliamentary consensus on important policy issues by consulting with all relevant political groups, including the cantons, at an early stage of the legislative process. ${ }^{52}$ Consequently, the Federal

45 On this distinction see D. Braun, 'The Territorial Division of Power in Comparative Public Policy Research: An Assessment', in D. Braun (ed.), Public Policy and Federalism (Ashgate, 2000), pp. 27-56, at 30; H. Keman, 'Federalism and Policy Performance: A Conceptual and Empirical Inquiry', in U. Wachendorfer-Schmidt (ed.), Federalism and Political Performance (Routledge, 2000), pp. 196-227, at 197.

46 See W. Linder \& S. Mueller, Schweizerische Demokratie, $4^{\text {th }}$ edn (Haupt Verlag, 2017), pp. 220-3; P. Knoepfel, 'Regulative Politik in föderativen Staaten: das Beispiel der Umweltpolitik', in A. Benz \& G. Lehmbruch (eds), Föderalismus (Springer, 2002), pp. 306-32, at 311-2, 316; Vatter, n. 32 above, pp. 58-9.

47 See Swiss Federal Constitution, n. 27 above, Art. 45.

48 Ibid., Art. 147; in more detail, Federal Act on the Consultation Procedure, 18 Mar. 2005, No. 172.061, Art. 3; official titles: Bundesgesetz über das Vernehmlassungsverfahren (German), Loi fédérale sur la procédure de consultation (French), Legge federale sulla procedura di consultazione (Italian), available at: https://www.admin.ch/opc/en/classified-compilation/20032737/index.html (non-official English translation).

49 See Swiss Federal Constitution, n. 27 above, Art. 141(1)(a) and (d).

50 See A.H. Trechsel \& P. Sciarini, 'Direct Democracy in Switzerland: Do Elites Matter?' (1998) 33(1) European Journal of Political Research, pp. 99-124, at 103-4.

51 A. Vatter, Das politische System der Schweiz, $3^{\text {rd }}$ edn (Nomos, 2017), p. 370.

52 Trechsel \& Sciarini, n. 50 above, p. 119 (finding that '[a] large consensus among the elite, elaborated during the pre-parliamentary and the parliamentary phases of the legislative process, significantly reduces the probability that a political actor shall attack a bill, forcing a popular vote'); A. Vatter, 'Consensus and Direct Democracy: Conceptual and Empirical Linkages' (2000) 38(2) European Journal of Political Research, pp. 171-92; A. Lijphart, Patterns of Democracy: Government Forms and Performance in Thirty-Six Countries, $2^{\text {nd }}$ edn (Yale University Press, 2012), p. 221; see also L. Neidhart, Plebiszit und pluralitäre Demokratie: Eine Analyse der Funktion des schweizerischen Gesetzesreferendums (Francke, 1970), pp. 287-8, 313-4 (developing his canonical theory according to which the optional referendum transferred Switzerland from a 'plebiscitarian' into a 'bargaining' democracy); A. Vatter, R. Freiburghaus \& A. Arens, 'Coming a Long Way: Switzerland's Transformation from a Majoritarian to a Consensus Democracy (1848-2018) (2020) 27(6) Democratization, pp. 970-89, at 975 (on the role of the optional referendum in the transformation from a majoritarian to a consensus democracy). 
Parliament almost always shies away from enacting a federal statutory law against concerted opposition from the cantons. ${ }^{53}$

\section{Taxing powers and fiscal autonomy}

The cantons have their own financial resources, levying personal income and corporate taxes set at their own rates. ${ }^{54}$ Tax competition is but one element of Switzerland's fiscal federalism. Cantons with ample resources and the Federation are all under a constitutional obligation to finance substantial transfers to cantons with fewer resources. ${ }^{55}$

\section{Municipal autonomy}

Municipalities (local government), of which there existed 2,172 at 1 January 2021, ${ }^{56}$ form a third layer of political governance below the Federation and the cantons. It is for the cantons to determine the scope of municipal autonomy. ${ }^{57}$ Municipalities have a dual role. On the one hand, they are autonomous units of self-government and self-administration; on the other hand, they are answerable to their canton and implement its laws and regulations. Overall, the municipalities in Switzerland are found to be the most autonomous units of local government in Europe. ${ }^{58}$ They spend about a quarter of Switzerland's total public expenditure. ${ }^{59}$

\section{ARCHITECTURE OF SWISS CLIMATE CHANGE LAW: UNITARY COMMITMENTS AND ADMINISTRATIVE INTERLOCKING}

\subsection{Switzerland's GHG Footprint and its Commitments under International Law on Climate Change}

Small-scale federalism as an enduring legacy of 1848, with its 26 cantons and 2,172 municipalities, ${ }^{60}$ bears witness to the truth of the observation made by Denis de

53 Vatter, n. 32 above, pp. 53-7, 78, 83; on the consultation procedure see Section 2.2 ('Participation of the cantons in the decision-making process of the Federation') above.

54 Swiss Federal Constitution, n. 27 above, Arts 47(2) and 129(2) (expressively shielding the rates of direct taxes from federal harmonization); see also Federal Finance Administration (FFA), 'Swiss Public Finances: 2018-2021' (2020), p. 6, Fig. 1, and underlying link to table (stating that the cantons spent $40.6 \%$ and the Federation $32.7 \%$ of total public expenditure in 2018), available at: https://www. newsd.admin.ch/newsd/message/attachments/63087.pdf.

55 See Swiss Federal Constitution, n. 27 above, Art. 135 (on 'equalization of financial resources and burdens') and, in more detail, Federal Act on the Equalization of Finances and Burden, 3 Oct. 2003, No. 613.2; official titles: Bundesgesetz über den Finanz- und Lastenausgleich (German), Loi fédérale sur la péréquation financière et la compensation des charges (French), Legge federale concernente la perequazione finanziaria e la compensazione degli oneri (Italian), available at: https://www.admin.ch/opc/fr/ classified-compilation/20012239/index.html.

56 See Federal Statistical Office, 'Répertoire officiel des communes de Suisse', 17 Dec. 2020, available at: https://www.bfs.admin.ch/bfs/fr/home/bases-statistiques/repertoire-officiel-communes-suisse.assetdetail. 15264524.html.

57 Swiss Federal Constitution, n. 27 above, Art. 50(1).

58 A. Ladner et al., Patterns of Local Autonomy in Europe (Palgrave Macmillan, 2019), p. 236 (ranking 36 European countries).

59 FFA, n. 54 above $(22.3 \%$ in 2018).

60 See Section 1 above, incl. nn. 10 and 11. 
Rougemont, a cultural theorist and influential proponent of European unification, that federalism rests 'upon the fondness for complexity' ${ }^{61}$ It also shapes the architecture of domestic climate change law. As foreign relations are a federal power, ${ }^{62}$ the federal government represents the Swiss Confederation (Switzerland) - the Federation and the cantons in their entirety - at the international level as a subject of public international law. The Federation is entitled to conclude international treaties on all subject matters. ${ }^{63}$ Norms of international treaties become part of Swiss federal law upon ratification ('monism'). ${ }^{64}$ In the domain of international law on climate change, Switzerland ratified the 1992 United Nations Framework Convention on Climate Change (UNFCCC), ${ }^{65}$ the 1997 Kyoto Protocol including the 2012 Doha Amendment, ${ }^{66}$ and the 2015 Paris Agreement. ${ }^{67}$ With regard to the latter, Switzerland pledged 'to reduce its greenhouse gas emissions by 50 percent by 2030 compared to 1990 levels' ${ }^{68}$ Between 1990 and 2016, domestic GHG emissions decreased by $10 \%$ and stood at 5.6 tonnes of $\mathrm{CO}_{2}$ equivalents per capita in $2015 .{ }^{69}$ Taking into account all consumptionbased emissions occurring on Swiss territory and abroad, including imported goods and international air travel, Switzerland's GHG footprint stands at 14 tonnes per capita per year, well above the global average of 6 tonnes. $^{70}$

In domestic law, the targets derived from Switzerland's pledges under international law and all measures to reduce those GHG emissions that are attributable to the use of fossil fuels as energy sources are stipulated in the Federal Act on the Reduction of $\mathrm{CO}_{2}$ Emissions (Federal $\mathrm{CO}_{2}$ Act). ${ }^{71}$ The Federal $\mathrm{CO}_{2}$ Ordinance, ${ }^{72}$ issued by the Federal Council, specifies the provisions of the Federal $\mathrm{CO}_{2}$ Act. The Ordinance sets out interim reduction targets for the transport, industry, and building sectors ${ }^{73}$ in order to

61 Denis de Rougemont, 'L'attitude fédéraliste', in Rapport du premier congrès annuel de l'U.E.F. à Montreux (1947), pp. 8-16, at 14 ('Le fédéralisme repose sur l'amour de la complexité ...').

62 Swiss Federal Constitution, n. 27 above, Art. 54(1).

63 See, e.g., Swiss Federal Court, n. 44 above, Decision 96 I 737, 23 Dec. 1970, s. 3.

64 See, e.g., Swiss Federal Court, n. 44 above, Decision 94 I 669, 22 Nov. 1968, s. 2.

65 New York (US), 9 May 1992, in force 21 Mar. 1994, available at: https:/unfccc.int/resource/docs/ convkp/conveng.pdf (ratified by Switzerland on 10 Dec. 1993, No. 0.814.01, available at: https:/www.admin.ch/opc/fr/classified-compilation/19920113/index.html; authentic French version).

66 N. 13 above.

67 Paris (France), 12 Dec. 2015, in force 4 Nov. 2016, available at: https://unfccc.int/sites/default/files/english_paris_agreement.pdf (ratified by Switzerland on 6 Oct. 2017, No. 0.814.012, available at: https://www.admin.ch/opc/fr/classified-compilation/20162916/index.html (authentic French version)).

68 UNFCCC Secretariat, 'Switzerland's Intended Nationally Determined Contribution (INDC) and Clarifying Information', 27 Feb. 2015, p. 1, available at: https:/www4.unfccc.int/sites/ndcstaging/ PublishedDocuments/Switzerland \%20First/15\%2002\%2027_INDC\%20Contribution \%20of \%20 Switzerland.pdf.

69 Swiss Federal Council, 'Environment Switzerland 2018', p. 83, available at: https://www.bafu.admin.ch/ er2018.

70 Ibid., p. 20.

71 Federal Act on the Reduction of $\mathrm{CO}_{2}$ Emissions, 23 Dec. 2011, No. 641.71; official titles: Bundesgesetz über die Reduktion der $\mathrm{CO}_{2}$-Emissionen (German), Loi fédérale sur la réduction des émissions de $\mathrm{CO}_{2}$ (French), Legge federale sulla riduzione delle emissioni di $\mathrm{CO}_{2}$ (Italian), available at: https://www.admin.ch/opc/en/classified-compilation/20091310/index.html (non-official English translation).

72 See Section 2.2 ('Symmetrical federalism') above.

73 Federal $\mathrm{CO}_{2}$ Ordinance, n. 13 above, Art. 3(1). 
continually assess whether Switzerland is on track to meet its overall targets. While both the industry and building sectors met their interim targets by reducing their GHG emissions by $18 \%$ and $26 \%$ respectively, the transport sector increased its emissions by $4 \%$ compared with its 1990 level. ${ }^{74}$ As the main source of GHG emissions, transport was responsible for $32 \%$ of all GHG emissions in $2015^{75}$ and $37.7 \%$ of Switzerland's total energy consumption in $2019 .{ }^{76}$ Road transport $(70.1 \%)$ and international air travel $(27.5 \%)$ cause the vast majority of the sector's GHG emissions, while the share attributable to railways stands at less than $0.15 \% .{ }^{77}$ This is largely as a result of the remarkably light GHG footprint of the Swiss electricity sector, with $56.4 \%$ of total electricity production in 2019 derived from hydropower, 35.2\% from nuclear power, $4.2 \%$ from conventional thermal power and district heating plants, $4.2 \%$ from 'new renewable' sources (wood, wind, solar, waste), and none from coal. ${ }^{78}$ Overall, Switzerland is likely to have missed the target of reducing its GHG emissions by at least $20 \%$ by 2020 measured against its 1990 levels, based on the most recent available data. ${ }^{79}$

\subsection{Broad Federal Powers: \\ Federal $\mathrm{CO}_{2}$ Act as the Centrepiece of Domestic Climate Change Law}

The Federal Constitution confers on the Federation substantial legislative powers regarding mitigating climate change. Regulating the electricity market, ${ }^{80}$ the use of energy by installations, vehicles and appliances, ${ }^{81}$ and nuclear energy ${ }^{82}$ are all federal powers. The Federation, furthermore, may enact principles on 'the use of local and renewable energy sources' and 'the economic and efficient use of energy'. ${ }^{83}$ Limiting federal powers to stipulate mere 'principles' as opposed to detailed regulation is a technique that the Swiss Federal Constitution often applies in the realm of environmental protection, notably with regard to spatial planning, water conservation, fishing, hunting, and forest conservation. ${ }^{84}$ This technique aims to strike a balance between ensuring

74 Swiss Federal Council, n. 69 above, p. 82.

75 Ibid.

76 Federal Office of Energy, 'Statistique globale suisse de l'énergie 2019' (2020), p. 10, available at: https://www.bfe.admin.ch/bfe/fr/home/approvisionnement/statistiques-et-geodonnees/statistiques-de-lenergie/ statistique-globale-de-l-energie.html.

See Federal Office for the Environment, 'Emissions de gaz à effet de serre de la Suisse 1990-2018' (2020), available at: https:/www.bafu.admin.ch/dam/bafu/fr/dokumente/klima/fachinfo-daten/THG_ Inventar_Daten.xlsx.download.xlsx/Evolution_emissions_GES_depuis_1990.xlsx.

78 Swiss Federal Office of Energy, 'Statistique suisse de l'électricité 2019' (2020), pp. 2, 6, available at: https://www.bfe.admin.ch/bfe/fr/home/approvisionnement/statistiques-et-geodonnees/statistiquesde-lenergie/statistique-de-l-electricite.html.

79 See Federal Office for the Environment, 'Switzerland's Greenhouse Gas Inventory 1990-2019: National Inventory Report' (2021), pp. 14-6, available at: https://www.bafu.admin.ch/dam/bafu/en/dokumente/ klima/klima-climatereporting/National_Inventory_Report_CHE.pdf.download.pdf/National_Inventory_ Report_CHE_2021.pdf. The inventory report covering 2020 is due to be published in Apr. 2022.

80 Swiss Federal Constitution, n. 27 above, Art. 91(1) (transport and supply of electricity).

81 Ibid., Art. 89(3) $1^{\text {st }}$ sentence.

82 Ibid., Art. 90.

83 Ibid., Art. 89(2).

84 Ibid., Arts 75(1), 76(2), 77(2) and 79. 
the same level of protection nationwide on the one hand, and granting the cantons discretion in adjusting the public interests at stake to local circumstances on the other hand. Regulating energy consumption in buildings is an area in which the delimitation of powers between the Federation and the cantons is 'particularly complex': ${ }^{85}$ the cantons are 'primarily' responsible, according to the text of the Federal Constitution. ${ }^{86}$ Federal statutory law not only commits the cantons to make use of their powers ${ }^{87}$ but also to file a yearly report with the Federal administration on the measures taken. ${ }^{88}$

Together with various federal powers on energy policy, ${ }^{89}$ the federal power on the protection of the environment ${ }^{90}$ forms the constitutional basis of the Federal $\mathrm{CO}_{2}$ Act. ${ }^{91}$ This comprehensive enactment, initially entered into force on 1 May 2000, ${ }^{92}$ constitutes the centrepiece of Swiss domestic climate change law. On 25 September 2020, the Federal Parliament adopted a total revision of the Act for the period beyond $2020 .^{93}$ The $\mathrm{CO}_{2}$ levy provided for by the Federal $\mathrm{CO}_{2}$ Act forms 'the backbone of Swiss climate policy'. ${ }^{94}$ The levy is collected on the production, extraction and import of 'thermal fuels' (heating oil, natural gas, coal, and so on) as opposed to 'motor fuels' (petrol, diesel, kerosene, and so on). ${ }^{95}$ The rate of the levy has risen to Swiss francs (CHF) 96 (EUR 90/USD 106) per tonne of $\mathrm{CO}_{2}$ since $2018^{96}$ and may increase to CHF 120, depending on whether interim reduction targets are met. ${ }^{97}$ According to

85 Swiss Federal Court, n. 44 above, Decision 1C_36/2011, 8 Feb. 2012, s. 3.2 ('ausgesprochen komplex').

86 Swiss Federal Constitution, n. 27 above, Art. 89(3) ('vor allem' (German), 'au premier chef' (French), 'in primo luogo' (Italian)). See generally J. Reich, ‘Auslegung mehrsprachigen Rechts unter den Bedingungen der Polyglossie in der Schweiz’, in F. Schorkopf \& Ch. Starck (eds), Rechtsvergleichung - Sprache Rechtsdogmatik (Nomos, 2019), pp. 145-73 (on multilingualism and legal interpretation), available at: https://doi.org/10.5167/uzh-179151.

87 Federal Act on Energy, 30 Sept. 2016, No. 730.0, Art. 45; official titles: Energiegesetz (German), Loi sur l'énergie (French), Legge federale sull'energia (Italian), available at: https://www.admin.ch/opc/fr/classified-compilation/20121295/index.html.

88 Art. 9(3) of the revised Federal $\mathrm{CO}_{2}$ Act of 25 Sept. 2020 (Federal $\mathrm{CO}_{2}$ Act (revised)), 'Loi fédérale sur la réduction des émissions de gaz à effet de serre', Federal Gazette 2020, pp. 7607-46, available at: https://www.fedlex.admin.ch/eli/fga/2020/2013/fr; Federal $\mathrm{CO}_{2}$ Act, n. 71 above, Art. 9(2); Federal $\mathrm{CO}_{2}$ Ordinance, n. 13 above, Art. 16.

89 Swiss Federal Constitution, n. 27 above, Art. 89.

90 Ibid., Art. 74(1).

91 See Federal $\mathrm{CO}_{2}$ Act (revised), n. 88 above, Preamble; Federal $\mathrm{CO}_{2}$ Act, n. 71 above, Preamble.

92 See Federal $\mathrm{CO}_{2}$ Act, n. 71 above, in its initial version of 8 Oct. 1999 ((2000) Recueil officiel du droit fédéral 979), available at: https:/www.admin.ch/opc/de/official-compilation/2000/979.pdf.

93 Federal $\mathrm{CO}_{2}$ Act (revised), n. 88 above. As an optional referendum (see Section 2.2 ('Participation of the cantons in the decision-making process of the Federation')) was launched against the revised Federal $\mathrm{CO}_{2}$-Act, a popular vote on the bill will take place on 13 June 2021; see Swiss Federal Council, 'Objets de la votation populaire du 13 juin 2021', 3 Feb. 2021, available at: https:/www.admin.ch/ gov/fr/accueil/documentation/communiques.msg-id-82214.html. The Federal Council will put the revised Federal $\mathrm{CO}_{2}$ Act into force should the referendum fail: Federal $\mathrm{CO}_{2}$ Act (revised), ibid., Art. $87(2)$.

94 See Swiss Federal Council, 'Message relatif à la révision totale de la loi sur le $\mathrm{CO}_{2}$ pour la période postérieure à 2020 du 1er décembre 2017', Federal Gazette 2018, pp. 229-372, at 244 ('... la pièce maîtresse de la politique climatique suisse ...'), available at: https://www.admin.ch/gov/fr/ accueil/droit-federal/feuille-federale.html.

95 See Federal $\mathrm{CO}_{2}$ Act, n. 71 above, Art. 29(1) in conjunction with (i.c.w.) Art. 2(1) and (2).

96 Ibid., Art. 29(1) i.c.w. Federal $\mathrm{CO}_{2}$ Ordinance, n. 13 above, Art. 94(1) c/1.

97 See Federal $\mathrm{CO}_{2}$ Act, n. 71 above, Art. 29(2) i.c.w. Federal $\mathrm{CO}_{2}$ Ordinance, n. 13 above, Art. 94. 
the text of the revised Federal $\mathrm{CO}_{2}$ Act, this rate may increase to a ceiling of CHF 210 per tonne of $\mathrm{CO}_{2}$ in $2021,{ }^{98}$ whereas a new levy on motor fuels would increase the price of gasoline by up to CHF 0.12 per litre by $2025 .{ }^{99}$ Similarly, a new levy on commercial passenger flights would increase the price of a ticket by between CHF 30 to 120, while certain private flights would be taxed at a rate of between CHF 500 to 3,000. ${ }^{100}$ Designed as an incentive tax, approximately two thirds of the revenue from the $\mathrm{CO}_{2}$ levy are redistributed to both the resident population and the companies residing in Switzerland, independent of consumption. ${ }^{101}$ The remaining third of revenues is invested into a climate fund to promote $\mathrm{CO}_{2}$ reduction measures in the building sector, secure loans for companies to develop and market equipment and processes to reduce GHG emissions, and subsidize measures to prevent damage to persons or property of considerable value that may arise as a consequence of the increased concentration of GHGs in the atmosphere. ${ }^{102}$ The emissions trading scheme established by the Federal $\mathrm{CO}_{2}$ Act (Swiss ETS) ${ }^{103}$ has been linked to the European Union Emissions Trading System (EU ETS) since 1 January 2020. ${ }^{104}$

\subsection{Administrative Interlocking between the Federation and the Cantons: Implementing Federal Climate Change Law}

As a result of the administrative interlocking between the Federation and the cantons as one of the core principles of Swiss federalism, the constitutionally ascribed federal power to legislate on climate change mitigation does not necessarily entail a corresponding power of the Federation to execute such laws by its own administration. Rather, it is for the cantons to implement and execute federal law, subject to an explicit provision by federal constitutional or federal statutory law to the contrary. ${ }^{105}$ The Federal $\mathrm{CO}_{2}$ Act, however, provides for exactly such an exception to the rule and entrusts its implementation to the Federal Administration in general ${ }^{106}$ and to the Federal Office for the Environment (FOEN) in particular. ${ }^{107}$ When the Federal $\mathrm{CO}_{2}$

\footnotetext{
98 See Federal $\mathrm{CO}_{2}$ Act (revised), n. 88 above, Art. 34(2).

99 Ibid., Art. 30(4).

100 Ibid., Arts 44(1) and 51(1).

${ }^{101}$ Ibid., Art. 53(2); Federal $\mathrm{CO}_{2}$ Act, n. 71 above, Arts 15-21.

102 See Federal $\mathrm{CO}_{2}$ Act (revised), n. 88 above, Arts 53-58; Federal $\mathrm{CO}_{2}$ Act, n. 71 above, Arts 31-32; Federal $\mathrm{CO}_{2}$ Ordinance, n. 13 above, Arts 34-36.

103 See Federal $\mathrm{CO}_{2}$ Act (revised), n. 88 above, Arts 21-29; Federal $\mathrm{CO}_{2}$ Act, n. 71 above, Arts 15-21; Federal $\mathrm{CO}_{2}$ Ordinance, n. 13 above, Arts 40-65.

104 Agreement between the European Union and the Swiss Confederation on the Linking of their Greenhouse Gas Emissions Trading Systems, Bern (Switzerland), 23. Nov 2017, in force 1 Jan. 2020, available at: https://eur-lex.europa.eu/legal-content/EN/TXT/?uri=CELEX\%3A22017A1207\%2801\%29 (ratified by Switzerland on 9. Dec. 2019, No. 0.814.011.268, available at: https://www.admin.ch/opc/fr/classified-compilation/20173209/index.html).

105 Swiss Federal Constitution, n. 27 above, Art. 74(3) (regarding environmental protection); see also Section 2.2 above.

${ }^{106}$ Federal $\mathrm{CO}_{2}$ Act (revised), n. 88 above, Art. 62(1); Federal $\mathrm{CO}_{2}$ Act, n. 71 above, Art. 39(1); see Section 3.1 above.

107 Federal $\mathrm{CO}_{2}$ Act (revised), n. 88 above, Art. 62(6); Federal $\mathrm{CO}_{2}$ Act, n. 71 above, Art. 39(4) (according to which the FOEN is the administrative agency responsible for all matters relating to climate protection, available at: https://www.bafu.admin.ch/en)
} 
Act was drafted in its initial form in 1997, the Federal Council ${ }^{108}$ argued that implementation by the Federal Administration would 'keep enforcement as simple as possible' and would 'ensure that companies ... operating nationwide' at various sites 'in several cantons' would be in a position to commit themselves to the then only voluntary schemes to reduce GHG emissions. ${ }^{109}$ The responsibility to ensure that $\mathrm{CO}_{2}$ emissions from 'buildings that are heated with fossil fuels' are reduced in compliance with the targets set out in the Federal $\mathrm{CO}_{2}$ Ordinance nevertheless rests with the cantons. ${ }^{110}$ The same applies for most areas covered by the Federal Environmental Protection Act (Federal EPA), ${ }^{111}$ with the exception of tasks closely related to climate change mitigation law, such as environmental tax incentives and emission limits for thermal and motor fuels. ${ }^{112}$ In matters of environmental law implemented by the cantons, the FOEN regularly publishes detailed guidelines specifying the provisions set out by federal environmental law in order to limit the exercise of discretion by the administrative agencies of the cantons. ${ }^{113}$

\subsection{Municipalities: Public Providers of Goods and Services}

Municipalities are autonomous yet they implement the laws of the canton to which they belong. ${ }^{114}$ In most cantons it is the municipalities that provide services such as waste management as well as the supply of electricity, water, and natural gas to both private households and industry. Most municipalities established their own public utility companies in the second half of the $19^{\text {th }}$ century in order to crowd out private monopolies in these industries. ${ }^{115}$ At around the turn of the $20^{\text {th }}$ century many cantons and urban municipalities established state-owned enterprises to build and operate hydropower plants and, beginning in the 1970 s, nuclear power stations. ${ }^{116}$

\subsection{Concluding Analysis: Flexible Administrative Interlocking}

In contrast to the usual constitutional implementation arrangement, the Federal $\mathrm{CO}_{2}$ Act is largely implemented by the Federal Administration. In view of Switzerland's

108 See Section 2.2 ('Symmetrical federalism') above.

109 See Swiss Federal Council, 'Message relatif à la loi fédérale sur la réduction des émissions de $\mathrm{CO}_{2}$ du 17 mars 1997', Federal Gazette 1997 III, pp. 395-466, at 444 (transl.), available at: https://www.fedlex. admin.ch/eli/fga/1997/3_410_395_370/fr.

${ }^{110}$ Federal $\mathrm{CO}_{2}$ Act (revised), n. 88 above, Art. 9; Federal $\mathrm{CO}_{2}$ Act, n. 71 above, Art. 9(1); on the Federal $\mathrm{CO}_{2}$ Ordinance, $n$. 13 above, see Section 3.1 above.

${ }^{111}$ Federal Act on the Protection of the Environment, 7 Oct. 1983, No. 814.01 (Federal EPA), Art. 9(2); official titles: Bundesgesetz über den Umweltschutz (German), Loi fédérale sur la protection de l'environnement' (French), Legge federale sulla protezione dell'ambiente (Italian), available at: https://www.admin. $\mathrm{ch} / \mathrm{opc} / \mathrm{en} / \mathrm{classified-compilation/19830267/index.html} \mathrm{(non-official} \mathrm{English} \mathrm{translation);} \mathrm{see} \mathrm{also}$ n. 105 above.

112 Ibid., Arts 42(2) and 41(1).

113 Ibid., Art. 38 (title); see in more detail A. Griffel, Umweltrecht, $2^{\text {nd }}$ edn (Dike, 2019), pp. 10-46.

114 See Section 2.2 ('Municipal autonomy') above.

115 J. Reich, Grundsatz der Wirtschaftsfreiheit (Dike, 2011), pp. 130-3; D. Kurz, 'Services industriels' (1 Dec. 2010), in Dictionnaire historique de la Suisse, available at: https:/hls-dhs-dss.ch/fr/articles/ 026450/2010-12-01.

116 Reich, n. 115 above, pp. 132-3; S. Paquier, 'Sociétés électriques' (26 Jan. 2016), in Dictionnaire historique de la Suisse, available at: https:/hls-dhs-dss.ch/fr/articles/042014/2016-01-26. 
small-scale federalism, this solution can be justified not only by the demands of private companies with sites in several cantons ${ }^{117}$ but also on practical grounds. The administration of financial incentives such as the $\mathrm{CO}_{2}$ levy or the Swiss ETS ${ }^{118}$ by 26 different administrative agencies would involve extensive effort and require each of these agencies to have specialized expertise at their disposal. The architecture of domestic climate change law therefore indicates that the constitutional framework of federalism in place since 1848 provides for both stability and, with regard to the implementation of laws, a degree of flexibility. Administrative interlocking between the Federation and the cantons thus remains an important feature of climate change law as it is, first and foremost, for the cantons to regulate energy consumption in buildings ${ }^{119}$ - a sector responsible for $30.3 \%$ of all $\mathrm{CO}_{2}$ emissions ${ }^{120}$ and for $41.6 \%$ of all energy consumption. ${ }^{121}$ At the same time, the revenues from the $\mathrm{CO}_{2}$ levy, collected by the Federation, are the main source of the subsidies paid out by the cantons to landowners for investments to reduce the GHG emissions of their buildings. ${ }^{122}$ This complex intertwining extends all the way to the municipalities. As providers of goods and services, including electricity and natural gas, ${ }^{123}$ municipalities have a major role to play in domestic climate change law, as will be discussed in more detail below. ${ }^{124}$

\section{UNDERLYING POLITICAL AND ECONOMIC RATIONALES OF FEDERALISM}

\subsection{Economic Approaches to Federalism: 'One View of the Cathedral'}

The intertwining of powers and tasks across three layers of governance invites the question of the rationale for such complex arrangements. Certain strands of literature on federalism, rooted in political and constitutional economics, seek to identify how legal norms and institutions of federalism interact with individual behaviour. ${ }^{125}$ Such 'economic approaches to federalism' ${ }^{\text {, } 26}$ centre mainly on the effects of

\footnotetext{
${ }^{117}$ For this official explanation see Section 3.3 above, including n. 109.

118 See Section 3.2 above.

119 See Section 3.3 above.

${ }^{120}$ Federal Office for the Environment, 'Émissions de gaz à effet de serre visées par la loi sur le $\mathrm{CO}_{2}$ révisée et par le Protocole de Kyoto (...) (2013-2020)' (2020), pp. 15-6, available at: https://www.bafu.admin.ch/ dam/bafu/fr/dokumente/klima/fachinfo-daten/CO2_Statistik.pdf.download.pdf/CO2_Publikation_fr_201907.pdf.

121 Swiss Federal Office of Energy, 'Analyse des schweizerischen Energieverbrauchs 2000-2019 nach Verwendungszwecken' (2020), p. 64, available at: https:/www.bfe.admin.ch/bfe/en/home/supply/statistics-and-geodata/energy-statistics/analysis-of-energy-consumption-by-specific-use.html.

122 See Section 3.2 above.

123 See Section 3.4 above.

124 See Sections 6.1-6.3 below.

125 See, e.g., S. Voigt, 'Positive Constitutional Economics II: A Survey of Recent Developments' (2011) 146(1-2) Public Choice, pp. 205-56, at 205-13, 230-4 (for an overview of positive constitutional economics and an analysis of federalism on those grounds).

126 See R.P. Inman \& D.L. Rubinfield, 'Economics of Federalism', in F. Parisi (ed.), The Oxford Handbook of Law and Economics, Vol. 3: Public Law and Legal Institutions (Oxford University Press, 2017), pp. 84-105, at 84 ('economic theory of federalism').
} 
competition between different political entities within a federal polity. ${ }^{127}$ While the aim of climate change policies - to reduce GHG emissions - is clearly defined by the commitments made under international law, ${ }^{128}$ there are multiple policy options to achieve this goal. The insights provided by economic approaches centring on competition between political entities can therefore enable considerations of whether the architecture of Swiss climate change law is likely to deliver beneficial effects. The underlying concept of public goods economy resembling a marketplace, as sketched below, offers but 'one view of the cathedral', ${ }^{129}$ and thus conveys, as any other theoretical and analytical approach would, one of several possible perspectives.

\subsection{Competition in the Public Provision of Goods and Services}

According to economic approaches to federalism, one of the major benefits of federalism is derived from the theoretically plausible assumption that subnational entities can be expected to have accurate knowledge about both the preferences of the citizens and their willingness to pay with regard to goods and services provided by the government. ${ }^{130}$ This premise forms the analytical justification for organizing the powers of the various federal units according to the principle of subsidiarity. ${ }^{131}$ It presumes the ability of local governments to tailor their provision of government goods and services to the preferences of the local population. At the same time, as the transaction costs for an individual to exit a constituent unit are generally thought to be marginal in a federal state, the option of any resident 'to vote with his or her feet' and exit the territorial entity in question would compel local governments to provide their services efficiently. ${ }^{132}$ The same restrictive incentives would apply for local governments as to taxes, which embody the price for government services. As subnational governments of a federation compete for taxpaying citizens, they can be reasonably expected to have an incentive to cater for the preferences of these citizens and to set the price of their services accordingly. ${ }^{133}$ Empirical studies testing the theoretical expectation that

127 See Voigt, n. 125 above, p. 230 (stating that '[i]n a nutshell, the conjectured economic benefits of federalism are expected to arise from the competition between constituent governments').

128 See Section 3.1 above.

129 G. Calabresi \& A.D. Melamed, 'Property Rules, Liability Rules, and Inalienability: One View of the Cathedral' (1972) 85(6) Harvard Law Review, pp. 1089-128, at 1089-90, incl. fn 3 (from whom the phrase is derived, alluding to Claude Monet's series of paintings, made in 1892 and 1893, of the Cathedral of Rouen, region of Normandy (France), from different perspectives at various times of the day).

130 W.E. Oates, Fiscal Federalism (Harcourt Brace Jovanovich, 1972), p. 12.

131 Inman \& Rubinfeld, n. 23 above, p. 38. In this regard see Swiss Federal Constitution, n. 27 above, Art. 5a (according to which the principle of subsidiarity must be observed when government tasks are being allocated) and more specifically Art. 43a (on the allocation of tasks between the different layers of governance).

132 W.E. Oates, ‘An Essay on Fiscal Federalism' (1999) 37(3) Journal of Economic Literature, pp. 1120-49, at 1123 (outlining the theoretical framework); H.S. Banzhaf \& R.P. Walsh, 'Do People Vote with Their Feet? An Empirical Test of Tiebout' (2008) 98(3) American Economic Review, pp. 843-63 (finding strong empirical support that households 'vote with their feet' regarding environmental quality); on 'exit' see A.O. Hirschman, Exit, Voice, and Loyalty: Responses to Decline in Firms, Organizations, and States (Harvard University Press, 1970), pp. 22-9.

133 See Ch. Tiebout, 'A Pure Theory of Local Expenditures' (1956) 64(5) Journal of Political Economy, pp. 416-24; see also Inman \& Rubinfeld, n. 23 above, pp. 38-44, 57-63 (on the specific requirements 
such federal competition would actually induce a moderating effect on public spending, however, have shown mixed evidence. ${ }^{134}$

\subsection{Regulatory Competition and Policy Innovation}

Competition between subnational entities of a federal state not only extends to tax policy but to regulation more broadly. Federalism allows citizens to compare the performance of their own local government with that of another, which in turn may encourage local politicians and civil servants to adopt more efficient and beneficial policies (yardstick competition). ${ }^{135}$ This would turn constituent units into 'laboratories' experimenting with different public policies, allowing for beneficial policy innovation. ${ }^{136}$ Incentives for such 'laboratory federalism', ${ }^{137}$ however, are weakened by the fact that many policy innovations are not only risky and costly but may be easily copied when proved successful. ${ }^{138}$ This invites free riding and may justify subsidies by the central government to support innovating subnational entities. ${ }^{139}$ Whether, and to what degree, the theoretical expectation of yardstick competition within federal entities translates into practical results, ${ }^{140}$ and whether competition would enhance or rather weaken environmental standards, is disputed. The economic appeal of a sizeable internal market within a jurisdiction that is committed to high environmental standards may, under specific circumstances, trigger a federal dynamic leading to more ambitious environmental protection, as it is often inefficient to design products in compliance with multiple regulatory standards. ${ }^{141}$ According to some authors, the 1970 US Clean Air Act ${ }^{142}$

leading to such effects and on the failure of the traditional model to explain how merit goods such as education, housing, or public safety may be provided by local governments).

${ }^{134}$ For a generally positive assessment see Inman \& Rubinfeld, n. 23 above, pp. 44-8 (reviewing various more recent studies on the US); G. Brennan \& J. M. Buchanan, The Power to Tax: Analytic Foundations of a Fiscal Constitution (Cambridge University Press, 1980), pp. 168, 216; M. Brülhart \& M. Jametti, 'Does Tax Competition Tame the Leviathan?' (2019) 177(C) Journal of Public Economics, pp. 1-16, at 13-5; S. Mueller, A. Vatter \& T. Arnold, 'State Capture from Below? The Contradictory Effects of Decentralisation on Public Spending' (2017) 37(4) Journal of Public Policy, pp. 363-400, at 376-83; but see W.E. Oates, 'Searching for Leviathan: An Empirical Study' (1985) 75(4) American Economic Review, pp. 748-57, at 756 (according to whom 'a strong, systematic relationship between the size of government and the degree of centralization of the public sector ... does not exist').

135 On the theory of yardstick competition see A. Shleifer, 'A Theory of Yardstick Competition' (1985) 16(3) Rand Journal of Economics, pp. 319-27.

136 See New State Ice Co. v. Liebmann, 285 U.S. 262, 310-11 (1932) (Brandeis, J., dissenting).

137 Oates, n. 132 above, p. 1121.

138 See, e.g., S. Callander \& B. Harstad, 'Experimentation in Federal Systems' (2015) 130(2) The Quarterly Journal of Economics, pp. 951-1002, at 952-7, 987-8.

139 K.S. Strumpf, 'Does Government Decentralization Increase Policy Innovation?' (2002) 4(2) Journal of Public Economic Theory, pp. 207-41; Inman \& Rubinfeld, n. 23 above, p. 49.

140 See, e.g., C. Volden, 'States as Policy Laboratories: Emulating Success in the Children's Health Insurance Program' (2006) 50(2) American Journal of Political Science, pp. 294-312, at 310 (finding strong evidence that states with successful policies are more likely to be emulated); S. Rose-Ackerman, 'Risk Taking and Reelection: Does Federalism Promote Innovation?' (1980) 9(3) Journal of Legal Studies, pp. 593-616, at 614-6; H.J. Wiseman \& D. Owen, 'Federal Laboratories of Democracy' (2018) 52(2) UC Davis Law Review, pp. 1119-191.

${ }^{141}$ D. Vogel, Trading Up: Consumer and Environmental Regulation in a Global Economy (Harvard University Press, 1995), p. 268.

142 Clean Air Act (CAA), 42 U.S.C. $\$ 7401$ et seq. (1970). 
illustrates the beneficial results of such federal interstate competition. ${ }^{143}$ The Act allowed California to enact stricter car emissions standards, which were later adopted by the federal government, only to provoke the next cycle of 'iterative federalism' during which the federal government once again aligned itself with the higher Californian standard. ${ }^{144}$ This ability of the State of California, revoked by the Trump administration in $2019,{ }^{145}$ to effectively set the regulatory standards for the whole nation as a result of both its sizeable internal market and its policy of promoting stricter environmental regulation was coined the 'California effect'. ${ }^{146}$ In contrast to this dynamic, some scholars argue that federalism would result in lower standards, particularly in the realm of environmental policy. This more sceptical perspective is fuelled by the analytical assumption that any subnational entity, in rationally pursuing its narrow self-interest, would opt against higher environmental protection for fear of capital moving to other entities with lower and less costly standards. ${ }^{147}$ Regulatory competition in environmental matters would thus create 'pollution havens' 148 situated in entities with the weakest environmental regulation. ${ }^{149}$ While the empirical evidence on whether regulatory competition spurs such downward spirals within federal polities has so far remained mixed and unsystematic, most studies nonetheless point to a degree of strategic interaction between subnational entities, meaning that politicians tend to discern changes in environmental regulations in other jurisdictions when reviewing their own policies, albeit only as one of several relevant considerations. $^{150}$

143 See, e.g., A.E. Carlson, 'Iterative Federalism and Climate Change' (2009) 10(3) Northwestern University Law Review, pp. 1097-162, at 1099, 1109-28; Vogel, n. 141 above, pp. 249, 259, 268.

144 Vogel, n. 141 above, pp. 249, 259, 268; P.G. Fredriksson \& D.L. Millimet, 'Is There a "California Effect" in US Environmental Policymaking?’ (2002) 32(6) Regional Science and Urban Economics, pp. 737-64, at 760-1 (with a more cautious assessment).

145 US Environmental Protection Agency Press Office, 'Trump Administration Announces One National Program Rule on Federal Preemption of State Fuel Economy Standards', 19 Sept. 2019, available at: https://www.epa.gov/newsreleases/trump-administration-announces-one-national-program-rule-federalpreemption-state-fuel; for an assessment see J.H. Adler, 'Uncooperative Environmental Federalism 2.0' (2020) 71(5) Hastings Law Journal, pp. 1101-26, at 1119-23.

146 Vogel, n. 141 above, p. 5.

147 R.B. Stewart, 'Pyramids of Sacrifice? Problems of Federalism in Mandating State Implementation of National Environmental Policy' (1977) 86(6) Yale Law Journal, pp. 1196-272, at 1212; for a review of more recent literature see B.R. Dijkstra \& P.G. Fredriksson, 'Regulatory Environmental Federalism' (2010) 2(1) Annual Review of Resource Economics, pp. 319-39, at 328-30.

148 B.R. Copeland \& M.S. Taylor, 'Trade, Growth, and the Environment' (2004) 42(1) Journal of Economic Literature, pp. 7-71, at 9.

149 See D.C. Esty, 'Revitalizing Environmental Federalism' (1996) 95(3) Michigan Law Review, pp. 570653, at 627-36; but see R.L. Revesz, 'Federalism and Environmental Regulation: A Public Choice Analysis' (2001) 115(2) Harvard Law Review, pp. 553-641; more nuanced, S. Wälti, 'How Multilevel Structures Affect Environmental Policy in Industrialized Countries' (2004) 43(4) European Journal of Political Research, pp. 599-634, at 624-6; and Inman \& Rubinfeld, n. 23 above, p. 287-92.

150 See, inter alia, W.E. Oates \& P.R. Portney, 'The Political Economy of Environmental Policy', in K.-G. Mäler \& J.R. Vincent (eds), Handbook of Environmental Economics, Vol. 1 (Elsevier, 2003), pp. 325-54, at 346 (according to whom evidence for a 'race to the bottom' remained 'largely anecdotal'); for a nuanced empirical assessment see Wälti, n. 149 above; see also S.J. Basinger \& M. Hallerberg, 'Remodelling the Competition for Capital: How Domestic Politics Erases the Race to the Bottom' (2004) 98(2) American Political Science Review, pp. 261-76; D.M. Konisky, 'Regulatory Competition and Environmental Enforcement: Is There a Race to the Bottom?' (2007) 51(4) American Journal of Political Science, pp. 853-72, at 869; for a sceptical view see K.H. Engel, 'State Environmental 


\subsection{Concluding Analysis: Broad Federal Powers, Constrained Federal Competition}

The economic approach to federalism emphasizes, above all, the beneficial effects of competition between federal units for society and the individual alike. In the context of Swiss federalism, these advantageous consequences are most likely to be relevant for the provision of public goods, as it is mainly the municipalities that supply electricity, drinking water, and natural gas. ${ }^{151}$ Citizens, furthermore, have the right to participate in referenda and to launch popular initiatives (direct democracy) at all three levels of Swiss federalism. Citizens are thus entitled to take part in the decisionmaking process relating to matters such as the level of taxes or investment in local infrastructure. ${ }^{152}$ While the public provision of goods and services is an area where one can reasonably expect a degree of competition on the basis of insights provided by economic approaches to federalism, such effects appear less likely in the context of Switzerland's environmental policy. The broad federal powers for environmental protection ${ }^{153}$ can be expected largely to forestall regulatory competition in this realm. This applies even to the regulation of energy consumption in buildings, for which the cantons are in principle responsible, as the Federation not only has spelled out interim targets for the building sector to reduce GHG emissions, but moreover commits the cantons to report on the measures taken to reach these targets. ${ }^{154}$ Apart from the federal powers and provisions, analytical considerations do not warrant the assumption that a canton would be in a position to project its influence beyond its own borders according to the model of the aforementioned California effect, ${ }^{155}$ as none of the cantons have an internal market large enough to set regulatory standards for other cantons. ${ }^{156}$ In contrast to frameworks of dualist federalism, ${ }^{157}$ the cantons project their influence less through competition than through both their use of discretion when implementing federal law ${ }^{158}$ and their individual and collective participation in policy formulation at the federal level. ${ }^{159}$

Standard-Setting: Is There a Race and Is It to the Bottom?' (1996) 48(2) Hastings Law Journal, pp. 271398 , at 374-6.

151 See Section 3.4 above.

152 See J. Reich, 'Direkte Demokratie und völkerrechtliche Verpflichtungen im Konflikt' (2008) 46(1) Heidelberg Journal of International Law, pp. 979-1025, at 985-98, available at: https://doi.org/10. 5167/uzh-65343; see also Reich, n. 41 above, p. 280.

153 See Section 3.2 above.

154 See Section 3.2 above.

155 See Section 4.3 above.

156 See also R. Steurer, C. Clar \& J. Casado-Asensio, 'Climate Change Mitigation in Austria and Switzerland: The Pitfalls of Federalism in Greening Decentralized Building Policies' (2020) 44(1) Natural Resources Forum, pp. 89-108, at 100 (identifying a 'lack of mutual learning and subnational policy diffusion from pioneers to laggards' in their empirical study in line with the above analysis).

157 See Section 2.1 above.

158 See Section 2.2 ('Participation of the cantons in the decision-making process of the Federation') above.

159 See Section 2.2 ('Administrative interlocking') above, and Section 5.3 below. 


\section{SMALL-SCALE FEDERALISM: HORIZONTAL COOPERATION AND FEDERAL PRE-EMPTION}

\subsection{Symmetrical Federalism Despite Asymmetries}

Competition between federal entities not only presupposes legal autonomy at the subnational level but requires all layers of federalism to have the governmental and administrative capacity to make effective use of their autonomy. Such administrative expertise plays a pivotal role in highly technical matters such as implementing climate change mitigation law. ${ }^{160}$ As a result of Switzerland's small-scale federalism, all cantons are accorded similar powers but, on account of their small size, they often lack governmental and administrative capacity. ${ }^{161}$ Disparities among the cantons have substantially increased since 1848 when 'symmetrical federalism' was adopted as a constitutional principle. ${ }^{162}$ In 2020, six of the 26 cantons accounted for $59 \%$ of Switzerland's entire population. ${ }^{163}$ In the same year, the permanent residential population of the largest canton exceeded the smallest by a factor of 96 , whereas this number stood at 43 more than a century ago. ${ }^{164}$ Twenty of the 26 cantons have a permanent residential population of below half a million people while the population of only two cantons Zurich and Berne - exceeds one million. ${ }^{165}$ In 2020 the smallest municipality of Switzerland was inhabited by a dozen citizens; the most populous - the City of Zurich - counted roughly half a million inhabitants. ${ }^{166}$

\subsection{Horizontal Cooperative Federalism: Pooling Administrative Resources while Keeping the Federation at Bay}

On account of scarce administrative capacity and in an effort to represent collectively their interests at the federal level, cantons have increasingly pooled their administrative and governmental resources in institutionalized networks. ${ }^{167}$ The Federal Constitution expressively underscores this right of the cantons to 'establish common organisations and institutions' ${ }^{168}$ Formally, such organizations are often established as associations

160 See Section 3.5 above.

161 See, e.g., Vatter, n. 32 above, p. 60.

162 See Section 2.2 above.

163 Own calculation based on Federal Statistical Office, n. 11 above.

164 Ibid., and own calculation based on the data of 1 Dec. 1888 according to Statistical Bureau of the Federal Department of Home Affairs, Statistisches Jahrbuch der Schweiz 1891 (Orell Fuessli, 1891), p. 1, available at: https://www.bfs.admin.ch/bfsstatic/dam/assets/346245/master.

165 Own calculation based on Federal Statistical Office, n. 11 above.

166 See Regionalporträts 2020: Kennzablen aller Gemeinden (2020), (City of Zurich [415,367 inhabitants] v. Corippo [11 inhabitants]), available at https://www.bfs.admin.ch/bfs/en/home/statistics/regional-statistics/regional-portraits-key-figures/communes/data-explanations.assetdetail.11587763.html.

167 See, e.g., N. Bolleyer, 'Consociationalism and Intergovernmental Relations: Linking Internal and External Power-Sharing in the Swiss Federal Polity' (2006) 12(3) Swiss Political Science Review, pp. 1-34, at 11-22; K. Füglister \& F. Wasserfallen, 'Swiss Federalism in a Changing Environment' (2014) 12(4) Comparative European Politics, pp. 404-21, at 406-9; J. Schnabel \& S. Mueller, 'Vertical Influence or Horizontal Coordination? The Purpose of Intergovernmental Councils in Switzerland' (2017) 27(5) Regional \& Federal Studies, pp. 549-72; Vatter, n. 32 above, pp. 73-83.

168 Swiss Federal Constitution, n. 27 above, Art. 48(1). 
of federal private law. These intergovernmental networks, which are usually referred to as 'conferences', thus transcend the structures of public law that embed Swiss federalism. ${ }^{169}$ Deliberations within such conferences are reserved for members of the executive branches of the cantons and are closed to the public. The public is rarely consulted regarding documents of legal relevance, and the same goes for members of parliaments. The dominant role of the executive branches at the expense of the legislature, and the lack of transparency, public scrutiny and democratic accountability, have frequently attracted criticism. ${ }^{170}$ The cantons nevertheless perceive horizontal cooperation as an effective strategy not only to fend off additional federal powers but also to alleviate their strained administrative resources. ${ }^{171}$

In 1979, all 26 cantons established the Swiss Conference of Cantonal Energy Directors (CDEn) as an intergovernmental council to coordinate energy laws and policies. ${ }^{172}$ In view of the primary responsibility of the cantons to regulate energy consumption in buildings ${ }^{173}$ and the interim target for the reduction of GHG emissions in the building sector set down by federal law, ${ }^{174}$ the CDEn issued a detailed, nonbinding model law on energy efficiency standards in buildings (MoPEC 2014). ${ }^{175}$ As in other instances of horizontal cooperative federalism, each member of the CDEn has one vote. ${ }^{176}$ This transforms each of the 26 cantons into a veto player ${ }^{177}$ regardless of its size or administrative resources, thereby increasing the likelihood that the cantons will agree only on the lowest common denominator when deciding on guidelines such as MoPEC 2014. The unanimity requirement may consequently lead to various institutional pathologies that are often associated with intertwined decision-making structures of cooperative federalism. ${ }^{178}$ Organizations of cooperative federalism may thus lose their collective capacity to reach optimal decisions or end in political stalemate altogether. In line with these theoretically and analytically founded expectations, the few empirical studies on the issue provide a rather bleak assessment of horizontal cooperative federalism, fuelling the claim that the significant GHG reductions in the

169 But see Schnabel \& Mueller, n. 167 above, p. 552; Vatter, n. 32 above, p. 75 (according to whom 'conferences' are as such 'located outside the formal framework of Swiss federalism').

170 For a brief assessment see Vatter, n. 32 above, pp. 71-3.

171 Vatter, n. 32 above, pp. 66-8.

172 'Conférences des directeurs cantonaux de l'énergie (CDEn)', available at: https://www.endk.ch/fr. The English terminology is derived from Vatter, n. 32 above, p. 76.

173 Swiss Federal Constitution, n. 27 above, Art. 89(3); see Section 3.2 above.

174 See Section 3.1 above.

175 CDEn, 'Modèle de prescriptions énergétiques des cantons (MoPEC)', 9 Jan. 2015, available at: https://www.endk.ch/fr/politique-energetique/mopec?set_language=fr.

176 Statuts de la CDEn [Articles of Association], Art. 4(2), available at: https://www.endk.ch/de/ablage/endk1/20200402_EnDK\%20Statuten_d_f_.pdf.

177 See G. Tsebelis, Veto Players: How Political Institutions Work (Princeton University Press, 2002), pp. 136-43 (on 'veto players' in federal systems in general).

178 F.W. Scharpf, 'Die Politikverflechtungs-Falle: Europäische Integration und deutscher Föderalismus im Vergleich' (1985) 26(4) Politische Vierteljahresschrift, pp. 323-56, at 337-8 (identifying the unanimity requirement as the main source of the problem-solving deficit of cooperative federalism in both Germany and the European Community). 
building sector of $26 \%$ by 2015 , compared with the 1990 level, ${ }^{179}$ were achieved 'despite, not because of' interaction between the cantons. ${ }^{180}$

\subsection{Federal Pre-emption: Vertical Incentives for More Stringent Regulation within Horizontal Cooperative Federalism}

When the cantons, organized in institutions of horizontal cooperative federalism such as the CDEn, fail to agree on guidelines in line with the interim targets spelled out in the Federal $\mathrm{CO}_{2}$ Ordinance, this carries the risk of triggering federal regulation. Federal law takes precedence over the conflicting law of a canton. ${ }^{181}$ The latter is thus void and without effect when it is in contradiction with federal law ('federal pre-emption'). ${ }^{182}$ The federal level has broad powers in respect of both environmental protection and energy policy. With regard to energy consumption in buildings, it is the cantons that are, according to the vague wording of the Federal Constitution, 'primarily' responsible for enacting laws. ${ }^{183}$ The Federation is hence under a constitutional obligation to refrain from unduly exercising its powers. As explained above, such restraint is equally due on political grounds, given the right of eight cantons to launch a referendum against any federal statutory law. ${ }^{184}$ As a result of this optional referendum, the Federation hardly ever succeeds in overcoming concerted opposition from the cantons on specific policy issues. ${ }^{185}$ Legally, the Federal Parliament is nonetheless entitled to enact federal laws should it consider the guidelines of the cantons to be insufficient in respect of the interim targets for the building sector. ${ }^{186}$ The less closed the ranks of the cantons are on the issue, the more likely it is that the Federal Parliament will adopt federal regulations. Since the cantons usually prefer to prevent federal intervention, the shadow of federal pre-emption incentivizes the cantons and the CDEn alike to avoid adopting standards that could be deemed insufficient. In line with analytical assumptions, empirical studies mainly credit formal and informal interventions by the Federation with the substantial reductions of GHG emissions achieved in the building sector. ${ }^{187}$

179 See Section 3.1 above.

180 Steurer, Clar \& Casado-Asensio, n. 156 above, p. 100; J. Casado-Asensio \& R. Steurer, 'Mitigating Climate Change in a Federal Country Committed to the Kyoto Protocol: How Swiss Federalism Further Complicated an Already Complex Challenge' (2016) 49(3) Policy Sciences, pp. 257-79, at 257.

181 Swiss Federal Constitution, n. 27 above, Art. 49(1).

182 See, e.g., Swiss Federal Court, n. 44 above, Decision 145 I 26, 22 Jan. 2019, ss. 3.1 and 8.4. The term 'federal pre-emption' is derived from US constitutional law; see, e.g., E. Chemerinsky, Constitutional Law, $6^{\text {th }}$ edn (Aspen, 2019), pp. 419-43.

183 See Section 3.2 above.

184 See Section 2.2 ('Participation of the cantons in the decision-making process of the Federation') above. 185 Ibid.

186 See Federal $\mathrm{CO}_{2}$ Act (revised), n. 88 above, Art. 55, and Federal $\mathrm{CO}_{2}$ Act, n. 71 above, Art. 34 (both under the heading 'Reduction of $\mathrm{CO}_{2}$ emissions from buildings') and Federal EPA, n. 111 above, Art. 12(1)(a) and (d) (according to which the Federation may limit emissions by issuing 'maximum emission values' and 'regulations on construction and equipment').

187 See Steurer, Clar \& Casado-Asensio, n. 156 above, p. 100; Casado-Asensio \& Steurer, n. 180 above, pp. 274-5. 
This strategic interplay between guidelines drafted within institutions of horizontal federalism and federal pre-emption can be observed in the total revision of the Federal $\mathrm{CO}_{2}$ Act adopted by the Swiss Federal Parliament on 25 September $2020 .{ }^{188}$ Regarding the replacement of oil or natural gas heating systems in buildings, the MoPEC 2014 guidelines, drafted by the CDEn on behalf of the cantons, stipulate that $10 \%$ of current energy consumption must be compensated for by renewable energies (for example, boiler replacement plus solar panels for hot water). ${ }^{189}$ As this threshold was widely assessed as insufficient in view of the interim target for the building sector, the Federal Parliament enacted a more stringent nationwide emissions limit for buildings of 20 kilogrammes $(\mathrm{kg})$ of $\mathrm{CO}_{2}$ per year and square metre of building space as of 2023 , declining by $5 \mathrm{~kg}$ every five years, effectively banning new oil-fired heating systems altogether. ${ }^{190}$ From 2023 onwards, new buildings are generally not allowed to emit any $\mathrm{CO}_{2}$ from fossil fuels through their heating and water heating systems. ${ }^{191}$

\subsection{Concluding Analysis: Close Interaction between the Layers of Federalism to Avoid Federal Stalemate}

Cooperation between the cantons to draft guidelines and model laws has turned out to be the option preferred by the cantons to meet the challenges of scarce administrative capacity associated with small-scale federalism, while guarding against centralization. ${ }^{192}$ Such 'horizontal cooperative federalism' provides limited incentives for ambitious policies to mitigate climate change. ${ }^{193}$ On account of the intertwining of powers and responsibilities regarding energy consumption in buildings, guidelines drafted by the institutions of horizontal cooperative federalism that are manifestly inadequate in view of the interim targets for the building sector defined in the Federal $\mathrm{CO}_{2}$ Ordinance risk falling prey to federal pre-emption. ${ }^{194}$ In general, members of a federation involved in intertwined decision making might easily lose their collective capacity to reach optimal decisions (because of the unanimity requirement) and, moreover, may prove to be incapable of overcoming the institutional restrictions of policy entanglement through reform. ${ }^{195}$ The closely interwoven powers of the Federation and the cantons with regard to energy consumption in buildings suggest that such a federal stalemate ${ }^{196}$ is avoidable as long as one actor - in the Swiss case, the Federation - is constitutionally entitled ultimately to break the deadlock. The Federal Constitution, the Federal $\mathrm{CO}_{2}$ Act, and the Federal EPA all confer this

\footnotetext{
${ }^{188}$ See nn. 88 and 93 above.

189 See MoPEC 2014, n. 175 above, Art. 1.29-1.31.

190 See Federal $\mathrm{CO}_{2}$ Act (revised), n. 88 above, Art. 10(1)(a).

191 Ibid., Art. 10(1)(b).

192 See Section 5.2 above.

193 See Section 5.2 above.

194 See Section 5.3 above.

195 See F.W. Scharpf, 'The Joint-Decision Trap: Lessons from German Federalism and European Integration' (1988) 66(3) Public Administration, pp. 239-78, at 241-2, 267-8, 271.

196 F.W. Scharpf, 'The Joint-Decision Trap Revisited' (2006) 44(4) Journal of Common Market Studies, pp. 845-64.
} 
option on the Federation for the regulation of energy consumption in buildings. ${ }^{197}$ The Federal Parliament, however, can be expected to exercise restraint, given not only the respective constitutional obligation but the right of the cantons to put such a federal statutory law to a popular vote by launching an optional referendum. ${ }^{198}$

Against this backdrop, the main finding of the analysis of the interaction between the cantons and the Federation with regard to the building sector might be that administrative interlocking, in contrast to dualist federalism, provides the constituent units with an influential position in a wide array of policy matters, regardless of whether there exists a federal power in respect of specific policies. In order to countervail the associated potential for suboptimal decisions or obstruction in institutions of horizontal cooperative federalism owing to the unanimity requirement, constitutional flexibility regarding the procedures of federalism proves to be crucial. The Swiss Federal Constitution thus grants the Federation the option to retain the implementation of its own laws for the Federal Administration based on statutory law. ${ }^{199}$ On this basis, most climate change law is implemented by the Federal Administration, most notably by the FOEN, rather than by the cantons. ${ }^{200}$

\section{REGULATORY EXPERIMENTALISM OWING TO DIVERGENT PREFERENCES}

\subsection{Policy Innovation in Climate Change Law}

Federalism is routinely credited with promoting regulatory innovation. ${ }^{201}$ Switzerland's small-scale federalism, however, ostensibly offers limited incentives for policy innovation in climate change law. This is mainly a result of the broad federal powers in environmental and energy policy, scarce administrative resources and the limited expertise of many small cantons, and because the decision-making processes within institutions of horizontal federalism are prone to dampening ambitious environmental policies. ${ }^{202}$ As explained in more detail below, as a result of both the specific structure of the Swiss electricity industry ${ }^{203}$ and the considerable administrative capacity of urban municipalities, the latter are better positioned than cantons to act as regulatory laboratories for climate change mitigation policies within Swiss federalism. 204

\footnotetext{
197 See Sections 3.2 and 5.2., incl. n. 186, above.

198 See Sections 5.3 and 2.2 ('Participation of the cantons in the decision-making process of the Federation') above, incl. n. 53 .

199 Swiss Federal Constitution, n. 27 above, Art. 46(1); see Section 2.2 ('Administrative interlocking’) above, incl. n. 44.

200 See Section 3.3 above.

201 See Sections 4.3 and 4.4 above.

202 See Section 5.4 above.

203 See Section 6.2 below.

204 See Section 6.3 below.
} 


\subsection{The Swiss Electricity Industry: State Capitalism Embedded in a Market Economy}

General government expenditure is an indicator of the size of government. $^{205}$ Switzerland's government spending amounts to $34.2 \%$ of its gross domestic product. ${ }^{206}$ Apart from Lithuania and Ireland, this constitutes the lowest rate among the European members of the Organisation for Economic Co-operation and Development (OECD) and it is considerably below the corresponding figures for the US (38\%), the United Kingdom (41\%), and Austria $(49.2 \%) .{ }^{207}$ In the light of this, Switzerland appears to be an archetype of a free-market economy. The country's electricity industry, however, is a far cry from this archetype. As a result of aggressive public investment instigated in the second half of the $19^{\text {th }}$ century, ${ }^{208}$ the sector resembles a particular form of state capitalism. As little as $8.1 \%$ of the industry's nominal capital lies in private hands, while the lion's share is held by cantons $(61.7 \%)$ and municipalities $(26.6 \%){ }^{209}$ Liberalization of the sector since the $1990 \mathrm{~s}$ 'in the shadow of EU-regulation, ${ }^{210}$ has remained half-hearted. Whereas electricity utility companies are under an obligation to ensure the independence of network operation ('unbundling'), only end users with a consumption of more than 100 megawatt hours (Mwh) per year - which is around $1 \%$ - are currently entitled to choose their electricity supplier. ${ }^{211}$

\subsection{Urban Municipalities: Bundling Policy Formulation, Policy Implementation, and Administrative Capacities}

\section{The right to decide: aligning policies with citizens' preferences by direct democracy}

A particular interplay of factors - state capitalism in the electricity industry, ${ }^{212}$ the extensive autonomy of Swiss municipalities, ${ }^{213}$ considerable administrative capacity of urban municipalities, and the bundling of policy formulation ('right to decide') and policy implementation ('right to act') ${ }^{214}$ in individual political authorities (namely,

\footnotetext{
205 See, e.g., P.A. Samuelson \& W.A. Nordhaus, Economics, $19^{\text {th }}$ edn (McGraw-Hill, 2009), p. 304.

206 OECD, Government at a Glance 2019 (OECD, 2019), p. 71, available at: https://oi.org/10.1787/ $8 \mathrm{ccf5} 338$-en.

207 Ibid.

208 See Section 3.4 above.

209 Swiss Federal Office of Energy, n. 78 above, p. 43 (the remaining 1\% is indirectly held by the Federation, $2.6 \%$ by foreign investors).

${ }^{210}$ M. Jegen, 'Swiss Energy Policy and the Challenge of European Governance' (2009) 15(4) Swiss Political Science Review, pp. 577-602, at 580.

${ }^{211}$ Federal Act on Electricity Supply, 23 Mar. 2007, No. 734.7, Arts 10, 6(1) and (6), and 13; official titles: Bundesgesetz über die Stromversorgung' (German), Loi sur l'approvisionnement en électricité (French), Legge sull'approvvigionamento elettrico (Italian), available at: https://www.admin.ch/opc/fr/classifiedcompilation/20042411/index.html. The Federal Council announced in spring 2020 that it will draft legislation to further liberalize the market for electricity; see Swiss Federal Council, 'Le Conseil fédéral entend renforcer les énergies renouvelables indigènes et ouvrir le marché de l'électricité', 3 Apr. 2020, available at: https://www.uvek.admin.ch/uvek/fr/home/detec/medias/communiques-de-presse.msg-id-78665.html.

${ }^{212}$ See Section 6.2 above.

213 See Section 2.2 ('Administrative interlocking') above.

214 On the distinction see Section 3.2 above, including n. 45.
} 
each municipality) - allows for considerable innovation in environmental and energy policies at the level of local government. As part of their communal autonomy, urban municipalities such as Zurich, Geneva, Basel, and Berne formulate their own energy and environmental policies to the extent that they are in line with federal law. ${ }^{215}$ Urban municipalities can largely rely on their state-owned enterprises to implement their energy and environmental strategies. The policies are usually closely aligned with the preferences of a majority of their citizens on account of direct democracy, as the example of the Municipality (City) of Zurich illustrates. Even in urban municipalities with local parliaments, a small fraction of no more than $3 \%$ of all citizens has the right to trigger a referendum against an act decided by the municipal parliament. ${ }^{216}$ Three thousand citizens of the City of Zurich may launch a popular initiative to be decided at the ballot box. ${ }^{217} \mathrm{~A}$ referendum is mandatory in respect of amendments to the municipal constitution. ${ }^{218}$ The City of Zurich's constitutional commitment 'to achieve the goals of the 2,000-watt society, in particular a reduction in energy consumption to 2,000 watts of continuous output per inhabitant ${ }^{219}$ is therefore backed by a referendum. The same is true for the City's obligations to reduce its ' $\mathrm{CO}_{2}$ emissions to one tonne per inhabitant and year'. 220

\section{The right to act: state-owned enterprises implementing municipal policies}

EWZ, the City of Zurich's own electricity utility ${ }^{221}$ founded in 1892 , supplies all private households and most commercial premises in Zurich with electricity. It not only owns and operates more than a dozen hydroelectric power stations in Switzerland but is a direct or indirect shareholder in wind, solar, and nuclear power plants in Switzerland, Northern Europe, Spain, and France. ${ }^{222}$ In terms of administrative law, EWZ is, despite its economic activities, an agency of the municipal administration. ${ }^{223}$ EWZ is thus under an obligation to implement the environmental and energy strategies and policies enacted by the City's legislative and executive branches, in particular the

215 On federal pre-emption see Section 5.3 above.

216 Act on the Political Rights (Canton of Zurich), 1 Sept. 2003, No. 161, $\$ 157(4)$; official title: Gesetz über die politischen Rechte, available at: https://www.zh.ch/de/politik-staat/gesetze-beschluesse/gesetzessammlung/zhlex-ls/erlass-161-2003_09_01-2005_01_01-108.html.

217 Ibid., $\mathbb{1 5 7}$; Municipal Constitution of the City of Zurich, 26 Apr. 1970 (as at 26 Nov. 2017), No. 101.100, Art. 15(3); official title: Gemeindeordnung der Stadt Zürich, available at: https:/www.stadt-zuerich.ch/portal/de/index/politik_u_recht/amtliche_sammlung/inhaltsverzeichnis/1/101/ Gemeinde ordnung_der_Stadt_Zuerich.html.

218 Municipal Constitution of the City of Zurich, ibid., Art. 10(a).

219 Ibid., Art. $2^{\text {ter }}(2)(\mathrm{a})$.

${ }^{220}$ Ibid., Art. $2^{\text {ter }}(2)($ b).

${ }^{221}$ Elektrizitätswerk der Stadt Zürich (EWZ); see Decision of the Zurich City Council on the Structure and Tasks of the Administration, 26 Mar. 1997 (as at 11 Sept. 2019), No. 172.110, Art. 52; official title: Stadtratsbeschluss über die Departementsgliederung und -aufgaben (German), available at: https://www.stadt-zuerich.ch/portal/de/index/politik_u_recht/amtliche_sammlung/inhaltsverzeichnis/1/ 172/110.html.

222 See EWZ, Geschäfts- und Nachhaltigkeitsbericht 2018, June 2019, pp. 11, 28-30, 65, available at: https://www.ewz.ch/content/dam/ewz/GNB/geschaeftsberichte/ewz_GNB_2018.pdf.

223 See Decision of the Zurich City Council, n. 221 above, Art. 52. 
aforementioned 'goals of the 2000-watt society'. ${ }^{224}$ As a result, EWZ, among other responsibilities, is under an obligation to supply electricity exclusively from renewable sources, to advise its customers on measures to use electricity more efficiently, and to support private investment in photovoltaic systems or appliances using electricity particularly economically with subsidies. ${ }^{225}$ Swiss federalism therefore allows for policy innovation and experimentation at the local level and enables the direct implementation of such policies through local state-owned enterprises.

\section{4. 'Alpine OPEC': Diverging Interests of Mountainous Regions}

The wide degree of autonomy that federalism entails for cantons and municipalities with regard to energy policy may be harnessed in various and sometimes conflicting ways, potentially undermining climate change mitigation policies of other, subnational actors. A levy charged on the use of water resources highlights this feature of federalism. Managing water resources is a power of the cantons. ${ }^{26}$ The cantons are therefore entitled to levy fees on the use of water by hydroelectric power stations, ${ }^{227}$ the source of more than half of the electricity produced in Switzerland. ${ }^{228}$ Five of the 26 cantons, all located in the Alpine regions of Switzerland, levy $73.2 \%$ of all such fees. ${ }^{22}$ The charges represent between 13 and $23 \%$ of all fiscal income of these Alpine cantons ${ }^{230}$ but amount to about one fifth of the production costs of electricity from hydropower. $^{231}$ In 1981, some of the cantons that rely considerably on these fees on the use of water for budgeting reasons, established their own forum of horizontal cooperative federalism - the Government Conference of Alpine Cantons (RKGK). ${ }^{232}$ Because the RKGK represents the interests of its members in connection with natural resources rather robustly, it is sometimes ironically dubbed the 'Alpine OPEC' in allusion to the Organization of the Petroleum Exporting Countries (OPEC). ${ }^{233}$ The vigorous representation of interests by cantons in the RKGK, in striving to raise the levy charged on the use of water, sheds light on the divergent interests at the subnational level: whereas the

224 See Ordinance on Public Services of EWZ within the Framework of the 2000-Watt Targets, 2 Dec. 2015, No. 732.360; official title: Verordnung über gemeinwirtschaftliche Leistungen des Elektriziätswerks der Stadt Zürich (ewz) im Rahmen der 2000-Watt-Ziele (German), available at: https://www.stadt-zuerich. ch/portal/de/index/politik_u_recht/amtliche_sammlung/inhaltsverzeichnis/7/732/360-verordnung-uebergemeinwirtschaftliche-leistungen-des-elektr.html.

225 Ibid., Arts 1(2)(b), 4 and 6(1)(a) and (b).

226 Swiss Federal Constitution, n. 27 above, Art. 76(4) $1^{\text {st }}$ sentence.

227 Ibid., Art. 76(4) $2^{\text {nd }}$ sentence.

228 See Section 3.1 above.

229 Swiss Federal Council, 'Message sur la modification de la loi sur les forces hydrauliques' (2018) Federal Gazette 2018, pp. 3539-60, at 3543, available at: https:/www.admin.ch/gov/fr/accueil/droit-federal/ feuille-federale.html.

230 Ibid., p. 3542.

231 Ibid., p. 3549.

232 'Regierungskonferenz der Gebirgskantone RKGK', available at: http://www.rkgk.ch. The English terminology is derived from Vatter, n. 32 above, p. 76.

233 See, e.g., H. Stalder, 'Bundesrat kapituliert vor der Alpen-Opec', Neue Zürcher Zeitung, 25 May 2018, available at: https://www.nzz.ch/meinung/wasserzins-bundesrat-kapituliert-vor-der-alpen-opec-ld. 1388947. 
sparsely populated cantons of the Alpine regions largely favour a high levy on water used for electricity production, the urban and densely populated cantons and municipalities of the lowlands, such as the City of Zurich, tend to prefer lower rates in order to promote electricity from renewable sources. These urban cantons are also often those reaping the fiscal benefits of trade in electricity, as this trade is administered mostly through premises in urban regions of Switzerland while production predominately takes place in the mountains. ${ }^{234}$ As with other aspects of Swiss federalism, ${ }^{235}$ federal law entrusts the federal government with the task of avoiding a possible stalemate amidst conflicting interests: it is the Federal Parliament that determines the rate ceiling of fees on the use of water. ${ }^{236}$ To avoid distorting competition, the cantons are prohibited from levying lower charges on electricity being not only produced but used on their territory. $^{237}$

\subsection{Concluding Analysis: Experimentalism, Dissonance, and Resolution}

Economic approaches to federalism routinely credit federalism with enhancing the potential for policy innovation. ${ }^{238}$ Such theories often tend to refer to concepts of 'dualistic federalism, ${ }^{239}$ in which the spheres of the Federation and the constituent states are, by and large, clearly separated. ${ }^{240}$ Administrative interlocking, in contrast, presupposes both cooperation and burden sharing (transfer payments), and allows for the participation of the constituent units in the decision-making process of the Federation. ${ }^{241}$ As opposed to constitutional frameworks of dualistic federalism, the three layers of Swiss federalism are thus not neatly separated but closely intertwined. Energy policies of urban municipalities such as the City of Zurich attest that such close intertwining across the layers of federalism still provides room for policy experimentation in line with the preferences of the local citizens. ${ }^{242}$ Owing to both small-scale federalism and its political and legal intertwinement, different preferences regarding energy and environmental policies within the various subnational entities may interfere with each other and thus create dissonance. The levy charged on the use of water illustrates this phenomenon. ${ }^{243}$ On the one hand, the levy significantly raises the production costs

\footnotetext{
234 See Swiss Federal Court, n. 44 above, Decision 2C_495/2017, 27 May 2019 (declaring unlawful the taxation of the profits from trade in electricity at the premises of the plant).

235 See Section 5.4 above.

236 See Federal Act on the Utilization of Hydropower, 22 Dec. 1916, No. 721.80, Art. 49(1); official titles: Bundesgesetz über die Nutzbarmachung der Wasserkräfte (German), Loi fédérale sur l'utilisation des forces hydrauliques (French), Legge federale sull'utilizzazione delle forze idriche (Italian), available at: https://www.admin.ch/opc/fr/classified-compilation/19160015/index.html.

237 Ibid., Art. 49(3).

238 See Sections 4.1 and 4.3 above.

239 See Section 2.2 above.

240 See Sections 4.1 and 4.3 above.

241 See Section 2.2 ('Participation of the cantons in the decision-making process of the Federation' and 'Taxing powers and fiscal autonomy) above; Linder \& Mueller, n. 46 above, pp. 174, 210-2; Vatter, n. 32 above, pp. 27, 187 .

242 See Section 6.3 above.

243 See Section 6.4 above.
} 
of electricity from hydropower and thus undermines the energy policies of entities like the City of Zurich, which is committed to supplying its customers with electricity produced exclusively from renewable sources. Higher production costs as a result of levies entail the risk that lower-priced electricity produced from coal will be imported more often, while electricity from hydropower may be crowded out of the market. ${ }^{244}$ On the other hand, the levy on the use of water reflects the cantons' right to dispose of their own resources, and also demonstrates that the resource 'water' tends to become more valuable in the light of both the transition to more sustainable energy production and climate change. To the extent that such conflicting interests require an authoritative resolution, federal law again provides a way out of possible federal stalemate by granting the Federal Parliament the power to determine the rate ceiling of the levy charged on the use of water. ${ }^{245}$

The diverging priorities within the various subnational entities may thus interfere with each other and create dissonance. Against the backdrop of broad federal powers, it is ultimately for the Federation to determine which energy and environmental policies are given preference based on the experience of the different subnational units, should the conflict between the different regulatory approaches call for a resolution. ${ }^{246}$ As a consequence of the right of eight cantons to launch an optional referendum against any such federal statutory law, however, any decision by the Federation on the direction of energy and environmental policy constitutes the result of a prolonged procedure, which includes close consultation and bargaining between the Federation and the cantons. $^{247}$

\section{CONCLUSION: FLEXIBILITY, EXPERIMENTALISM, DISSONANCE, AND PROCEDURES TO AVOID STALEMATE}

Federalism is ostensibly misplaced to mitigate climate change as a global public good, as it may project the inadequate incentive structures existing at the international level onto the domestic domain. ${ }^{248}$ Yet both the architecture and the procedures of Switzerland's climate change law suggest that such concerns generally fail to materialize. Unlike dualistic federations such as the US, Swiss federalism is based on administrative interlocking leading to cooperation and bargaining across the different layers of federalism. ${ }^{249}$ The constitutional principles of Swiss federalism ${ }^{250}$ on implementing federal laws provide not only for flexibility but also allow the Federation to act on its

244 The validity of this argument depends largely on (i) market prices for electricity in western Europe, and (ii) the degree to which the Swiss market for electricity is and will be liberalized; on the latter see Section 6.2 above and Swiss Federal Council, n. 211 above.

245 See Section 6.4 above.

246 Ibid.

${ }^{247}$ See Section 2.2 ('Participation of the cantons in the decision-making process of the Federation') above.

248 See Section 1 above.

249 See Sections 2.1, 2.2 ('Administrative interlocking' and 'Participation of the cantons in the decision-making process of the Federation'), 3.3, 5.1 and 6.5 above.

250 See Sections 2.2 and 4.4 above. 
own in order to overcome potential stalemate. The Federation is entitled to depart from the constitutional rule according to which it is for the cantons to implement federal law on the basis of a provision of federal statutory law. ${ }^{251}$ As a result, it is the FOEN rather than the cantons that is entrusted with the implementation of almost all parts of the comprehensive Federal $\mathrm{CO}_{2}$ Act, the centrepiece of domestic climate change law. ${ }^{252}$ Even in areas of domestic climate change law for which the cantons are primarily responsible, such as energy consumption in buildings, ${ }^{253}$ the Federation may ultimately enact federal regulations that override the laws of the cantons. ${ }^{254}$ The formally unilateral right of the Federation to decide ${ }^{255}$ is likely not only to provide institutions of horizontal cooperative federalism with incentives to adopt more stringent regulations but also to avoid federal impasse. ${ }^{256}$ The Federation's right to decide, however, is severely restrained by the right of eight cantons or 50,000 citizens to launch a referendum against any federal statutory law decided by the Federal Parliament. Any decision by the Federation on the direction of energy and environmental policy therefore constitutes the result of a prolonged procedure, which includes close consultation between the Federation and the cantons. ${ }^{257}$

The main lessons from the Swiss experience regarding the relationship between laws designed to mitigate climate change and federalism therefore might be that small-scale federalism neither unavoidably weakens environmental standards nor necessarily leads to federal stalemate. This is on the condition that the legal architecture of domestic climate change law provides for considerable federal powers, a degree of institutional flexibility, robust formal channels of influence for subnational actors on policy formulation at the federal level, ample room for regulatory experimentalism at the lower layers of federalism, and the right to act conferred on the Federation to avoid political impasse among the constituent units.

\footnotetext{
251 Swiss Federal Constitution, n. 27 above, Art. 46(1); see Section 2.2 ('Administrative interlocking'), incl. n. 44 , above.

252 See Section 3.3 above.

253 See Section 3.2 above, incl. nn. 85-87.

254 See Section 5.3 above.

255 See Section 2.2 ('Administrative interlocking') above.

256 See Sections 5.1-5.4 above.

257 See Section 2.2 ('Participation of the cantons in the decision-making process of the Federation') above.
} 